This postprint is published in:

ChemMedChem, Volume 13, Issue 2, January 22, 2018, Pages 186-198

DOI: $10.1002 / \mathrm{cmdc} .201700549$

\title{
Synthesis and Evaluation of $N$-Phenylpyrrolamides as DNA Gyrase B Inhibitors
}

Martina Durcik, ${ }^{[\mathrm{a}]}$ Päivi Tammela, ${ }^{[\mathrm{b}]}$ Michaela Barančoková, ${ }^{[\mathrm{a}]}$ Tihomir Tomašič,${ }^{[\mathrm{a}]}$ Janez Ilaš, ${ }^{[\mathrm{a}]}$ Danijel Kikelj, ${ }^{\text {[a] }}$ and Nace Zidar*[a]

[a] Martina Durcik, Michaela Barančoková, Assist. Prof. Tihomir Tomašič, Assoc. Prof. Janez Ilaš, Prof. Danijel Kikelj, Assist. Prof. Nace Zidar

Faculty of Pharmacy, University of Ljubljana, Aškerčeva cesta 7, 1000 Ljubljana (Slovenia)

E-mail: nace.zidar@ffa.uni-lj.si

[b] Prof. Päivi Tammela

Drug Research Program, Division of Pharmaceutical Biosciences, Faculty of Pharmacy, University of Helsinki, P.O. Box 56 (Viikinkaari 5 E), Helsinki FI-00014 (Finland)

Supporting Information with full results of antibacterial activity of compounds, detailed experimental procedures, analytical data and NMR spectra of the representative compounds, and the ORCID identification numbers for the authors of this article can be found via the internet link.

\section{ABSTRACT}

ATP-competitive inhibitors of DNA gyrase and topoisomerase IV (topo IV) are among the most interesting classes of antibacterial drugs that do not have any representative in the antibacterial pipeline. We have developed thirty-two new $N$-phenylpyrrolamides and evaluated them against DNA gyrase and topoisomerase IV from Escherichia coli and Staphylococcus aureus. Antibacterial activities were studied against Gram-positive and Gram-negative bacterial strains. The most potent compound displayed an $\mathrm{IC}_{50}$ of $47 \mathrm{nM}$ against E. coli DNA gyrase, and a minimum inhibitory concentration (MIC) of $12.5 \mu \mathrm{M}$ against Gram-positive Enterococcus faecalis. Some compounds displayed good antibacterial activities against the efflux pump deficient E. coli strain (MICs =6.25 
$\mu \mathrm{M})$ and against wild type $E$. coli in the presence of efflux pump inhibitor PA $\beta \mathrm{N}(\mathrm{MIC}=3.13 \mu \mathrm{M})$. We describe here new findings regarding structure-activity relationship of $N$-phenylpyrrolamide DNA gyrase B inhibitors and explore factors that are important for antibacterial activity of this class of compounds.

\section{INTRODUCTION}

Infections are among the major causes of human morbidity and mortality and the pharmaceutical industry is not able to keep up with the growing needs for effective novel antibacterials. The main reason for this situation is the rapid adaptation of bacteria to antibiotics, which results in the development of resistance soon after antibacterial drugs are introduced to therapy. ${ }^{[1]}$ Another problem is the low number of new approved antibacterial drugs in the last decades, which is associated with the strict regulatory requirements and relatively low cost-to-benefit ratio for antibacterial R\&D compared to other pharmacological fields. ${ }^{[2][3]}$

Bacterial topoisomerases are enzymes that catalyse changes in DNA topology during DNA replication, transcription and recombination. They are essential in all bacteria but absent in higher eukaryotes, which makes them attractive targets for antibacterial drug discovery. DNA gyrase is involved primarily in the negative supercoiling of DNA, while topoisomerase IV is responsible mainly for the decatenation of the two daughter chromosomes after replication. DNA gyrase and topoisomerase IV both belong to type IIA topoisomerases. They are heterotetrameric enzymes composed of two pairs of subunits: two GyrA and two GyrB subunits in DNA gyrase, and two ParC and two ParE subunits in topoisomerase IV. The GyrA and GyrB subunits of DNA gyrase are similar in amino acid sequence to the ParC and ParE subunits of topoisomerase IV, respectively. The main function of GyrA/ParC is cleavage and reunion of DNA, whereas GyrB/ParE binds ATP, which is crucial for providing the energy for the conformational movements of the enzyme, required for the ligation process. ${ }^{[4]}$

There are two main mechanisms of action of drugs targeting DNA gyrase and topoisomerase IV. The first is stabilisation of the covalent enzyme-DNA complex, which is typical for the fluoroquinolone class of antibacterials. ${ }^{[5]}$ The presence of some serious side effects together with the growing bacterial resistance to fluoroquinolones has stimulated the search for inhibitors targeting various binding sites on DNA gyrase. ${ }^{[6]}$ The second possible mechanism of action of drugs targeting DNA gyrase and topoisomerase IV involves inhibition of ATP binding on the 
GyrB/ParE subunit. Novobiocin, a natural aminocoumarin antibiotic that was withdrawn from the clinic because of toxicity, is a classic example of ATP-competitive GyrB inhibitors. In recent decades, several new scaffolds have been identified as GyrB and/or ParE inhibitors, such as pyridylureas, ${ }^{[7]}$ pyrimidinoindoles, ${ }^{[8]}$ pyrrolopyrimidines, ${ }^{[9]}$ benzimidazole ureas, ${ }^{[10]}$ pyrrolamides, ${ }^{[11]}$ and pyrazolopyridones ${ }^{[12]}$ (Figure 1). Even though some of the new inhibitors have advanced to Phase I, none of them has so far reached clinical practice. ${ }^{[13]}$ In the present study, we describe a new series of DNA gyrase (GyrB) and topoisomerase IV (ParE) inhibitors, resulting in optimised on-target and antibacterial activities.

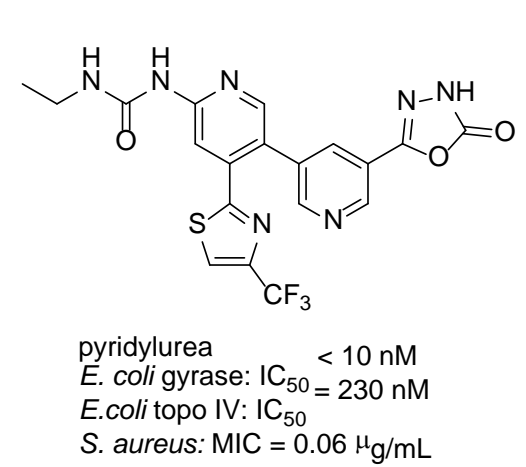

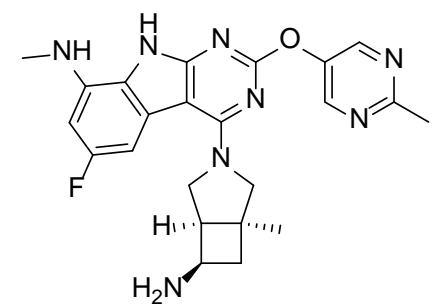

pyrimidinoindole $=0.3 \mathrm{nM}$ E. coli gyrase: $K_{\mathrm{i}}=0.9 \mathrm{nM}$ E. coli topo IV: $K_{\mathrm{i}}$

S. aureus: $\mathrm{MIC}=0.008 \mu \mathrm{g} / \mathrm{mL}$

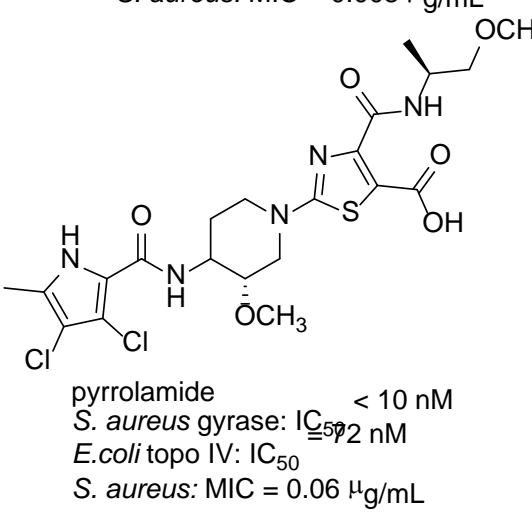

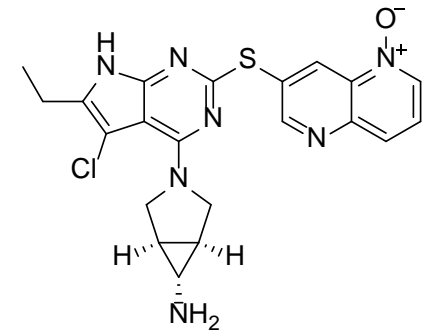

pyrrolopyrimidine $<0.3 \mathrm{nM}$ $E$. coli gyrase: $K_{\mathrm{i}}=1.7 \mathrm{nM}$ E. coli topo IV: $K_{\mathrm{i}}=1.7 \mathrm{nM}$ S. aureus: $\mathrm{MIC}<0.06 \mu \mathrm{g} / \mathrm{mL}$

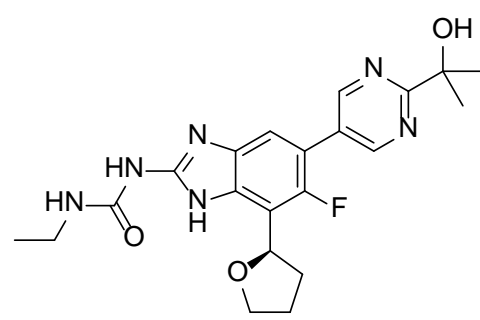

benzimidazole urea $<12 \mathrm{nM}$

S. aureus gyrase: $K_{\mathrm{i}}=9 \mathrm{nM}$

S. aureus topo IV: $K_{\mathrm{i}}$

S. aureus: $\mathrm{MIC}=0.032 \mu \mathrm{g} / \mathrm{mL}$

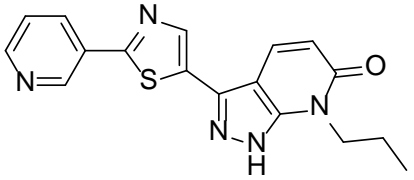

pyrazolopyridone $\quad=6 \mathrm{nM}$

S. aureus gyrase: $I C_{50}=183 \mathrm{nM}$

S. aureus topo IV: $\mathrm{IC}_{50}$

S. aureus: $\mathrm{MIC}=0.06 \mu \mathrm{g} / \mathrm{mL}$

Figure 1. Representative inhibitors of DNA gyrase (GyrB) and topoisomerase IV (ParE), and their IC $50, K_{\mathrm{i}}$ and $\mathrm{MIC}$ (S. aureus) values.

\section{RESULTS AND DISCUSSION}

Design. The design of the present series of compounds was based on the crystal structure of $\mathrm{N}$ phenylpyrrolamide inhibitor $\mathbf{A}$ in complex with E. coli DNA gyrase B (Figure 2, PDB code: 4ZVI), ${ }^{[14]}$ and was aimed at improving its GyrB/ParE inhibitory potency and antibacterial activity. Three structural types of compounds (type I-III, Figure 2) were prepared, in which we introduced modifications proposed by the detailed study of the binding mode of inhibitor $\mathbf{A}$ in the GyrB active 
site, and by molecular docking (Figure 3). In all structural types (I-III) we have retained the adjacent hydrogen bond donor (pyrrole $\mathrm{NH}$ ) and hydrogen bond acceptor (pyrrolamide $\mathrm{C}=\mathrm{O}$ ) groups that are necessary for establishing the H-bonding network with Asp73 (E. coli numbering) and the structurally conserved water molecule (Figure 2). The amide $\mathrm{NH}$ of the pyrrolamide moiety was left unsubstituted because it is important for indirect contacts with Asn46 through a crystal water molecule. In some derivatives, we have replaced the 4,5-dibromo- $1 H$-pyrrole group on the left-hand side of the molecules with 3,4-dichloro-5-methyl-1H-pyrrole. Thus far, replacing the 4,5dibromo- $1 H$-pyrrole moiety by 4-bromo- $1 H$-pyrrole, $1 H$-indole, or by 4,5 -dichloro- $1 H$-pyrrole resulted in weaker activity. ${ }^{[14-15]}$ The 3,4-dichloro-5-methyl-1H-pyrrole was selected because the chlorine atoms are slightly smaller than the bromine atoms and are thus proposed to bind more strongly, not only to DNA gyrase, but also to the slightly smaller binding pockets of $S$. aureus DNA gyrase and topoisomerase IV. ${ }^{[4 \mathrm{~b}, 16]}$ Additionally, the 3,4-dichloro-5-methylpyrrole moiety is found e.g. in kibdelomycin, a complex antibiotic isolated from extracts of the soil bacterium Kibdelosporangium sp., ${ }^{[17]}$ and in some pyrrolamide DNA gyrase B inhibitors developed by AstraZeneca. ${ }^{[11 \mathrm{~d}]}$

The right-hand side of the molecules was designed to contain groups able to form ionic interactions with Arg136 (e.g. carboxylic acid groups) or $\pi$-stacking interactions with the Glu50Arg76 salt bridge (e.g. 4-amino-2-hydroxybenzoic acid or 1,3,4-oxadiazol-2-one ring). Whereas type I compounds were all glycine derivatives, in some type II compounds, the carboxamide $\mathrm{N}$ substituent was varied from carboxymethyl $(n=1$, Figure 2$)$ to the 2-carboxyethyl group $(n=2$, Figure 2). In order to improve transport across the bacterial cell membranes, the ionizable terminal carboxylic acid functionality was replaced in some type I and type II compounds by its less acidic bioisostere 1,3,4-oxadiazol-2-one. The 1,3,4-oxadiazol-2-one ring was proposed to form similar interactions with Arg136 as does the terminal carboxylic group, but its lower acidity promises better permeability across bacterial membranes and, consequently, better antibacterial activity. ${ }^{[7]}$ Additionally, some type I and type II compounds with terminal hydrazide groups were analyzed.

With the type II series, we have introduced additional alkoxy substituents to the 3-position of the central benzene ring. The preliminary docking studies have indicated the possibility of additional hydrophobic contacts between these groups and the lipophilic floor of the enzyme formed by the amino acid residues Ile94, Ile78, Val120 and Val167 (Figure 3). The size of substituents was increased from methoxy, through isopropoxy, to the benzyloxy group. 
Based on the relatively high activity of one of our previously reported inhibitors with only a short $\mathrm{COCH}_{3}$ substituent on the para position of the central aminobenzene ring (i.e. $N$-(4-acetylphenyl)4,5-dibromo- $1 H$-pyrrole-2-carboxamide, $\left.\mathrm{IC}_{50}=1.6 \mu \mathrm{M}\right),{ }^{[15 \mathrm{~b}]}$ we decided to further explore the chemical space around this molecule by preparing a small library of its analogues (type III compounds, Figure 2). Analogues were prepared with carboxylic groups attached directly to the central phenyl ring ( $\mathbf{X}=\mathrm{OH}, \mathbf{Y}=\mathrm{H}$, Figure 2), compounds with an additional hydroxyl group on the phenyl ring ( $\mathbf{X}=\mathrm{OH}, \mathbf{Y}=\mathrm{OH}$, Figure 2), and compounds with an acetophenone functionality ( $\mathbf{X}=\mathrm{CH}_{3}, \mathbf{Y}=\mathrm{H}$, Figure 2). To determine the influence of increased length of the molecules on gyrase B and topoisomerase IV inhibition, we prepared a compound with an additional aromatic ring ( $\mathbf{X}=4-\mathrm{NH}_{2}-2-\mathrm{OH}-\left(\mathrm{C}_{6} \mathrm{H}_{3}\right)-\mathrm{COOH}, \mathbf{Y}=\mathrm{H}$, Figure 2). The structure-activity relationships (SAR) of all the prepared compounds were studied, enabling the essential structural elements for GyrB/ParE inhibition and for antibacterial activity to be determined.

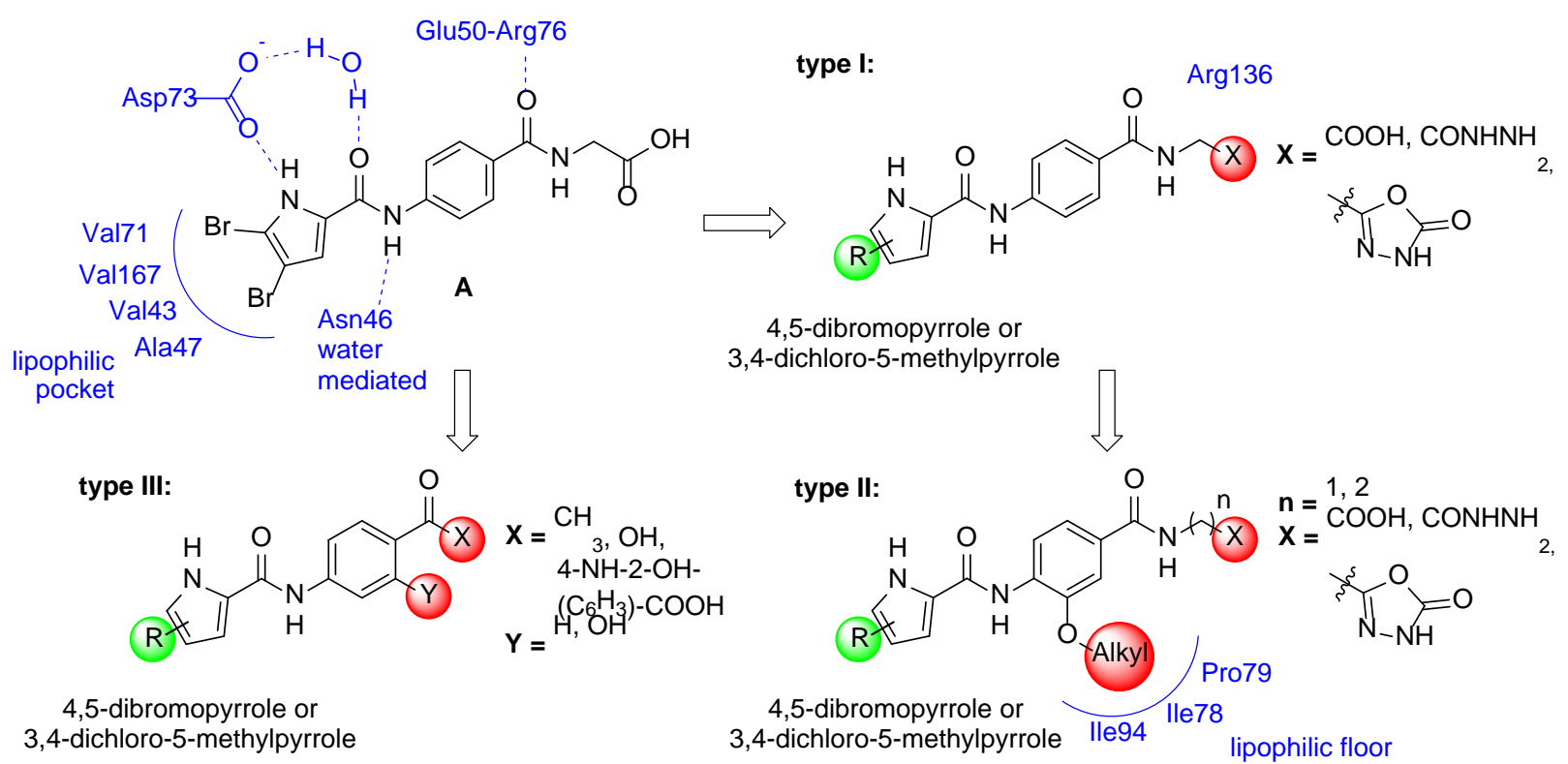

Figure 2. Design of three structural types (I-III) of $N$-phenylpyrrolamides as DNA gyrase B inhibitors, based on the co-crystal structure of the inhibitor A - GyrB (E. coli) (PDB code: 4ZVI ${ }^{[14]}$ ). 


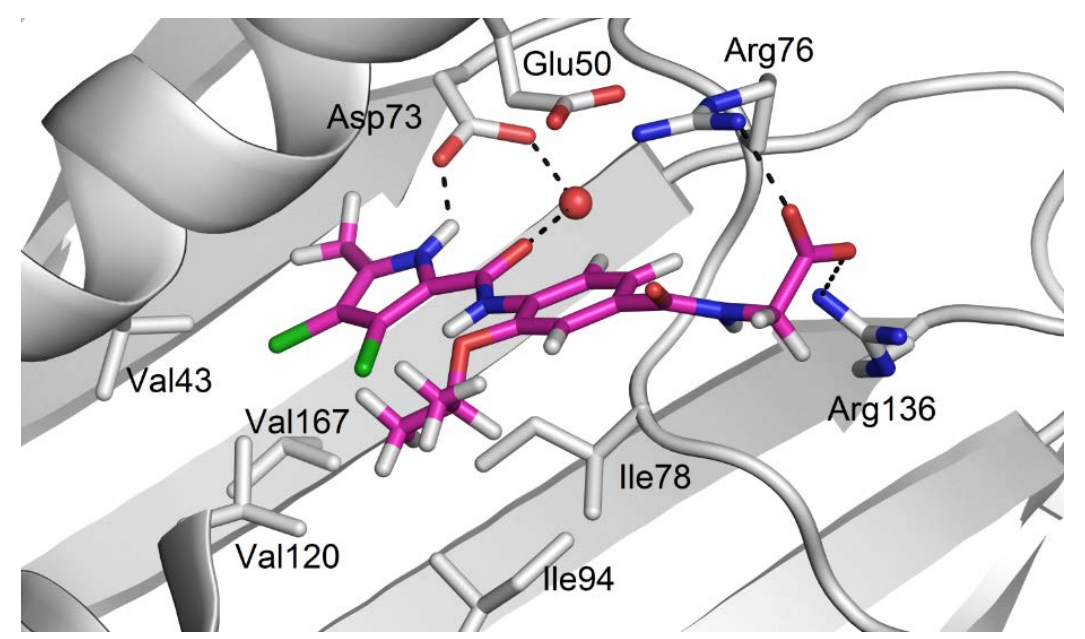

Figure 3. The docking binding mode of inhibitors 19f (in magenta) in the ATP binding site of E. coli DNA gyrase B (in grey, PDB code: $4 \mathrm{DUH}^{[18]}$ ). The ligand and the neighbouring protein side-chains are shown as stick models, coloured according to the chemical atom type (blue, N; red, O; orange, S; green, $\mathrm{Cl}$ ). Hydrogen bonds are indicated by black dotted lines.

Chemistry. The synthesis of type I compounds (7-11) is presented in Scheme 1. First, 4nitrobenzoyl chloride (1) was reacted with glycine methyl ester hydrochloride (2) in the presence of potassium carbonate to give compound $\mathbf{3}$. The nitro group of $\mathbf{3}$ was reduced by catalytic hydrogenation and the obtained amine $\mathbf{4}$ was coupled with 4,5-dibromopyrrole-2-carboxylic acid using $N, N, N^{\prime}, N^{\prime}$-tetramethyl-O-(benzotriazol-1-yl)uronium tetrafluoroborate (TBTU), to yield pyrrolamide 5, or with 3,4-dichloro-5-methylpyrrole-2-carboxylic acid chloride prepared in situ from the carboxylic acid using oxalyl chloride, to give pyrrolamide $\mathbf{6}$. Compound $\mathbf{7}$ was prepared by alkaline hydrolysis of methyl ester $\mathbf{6}$ while hydrazides $\mathbf{8}$ and $\mathbf{9}$ were prepared by heating $\mathbf{5}$ or $\mathbf{6}$ with hydrazine at $78{ }^{\circ} \mathrm{C}$. To obtain the target 1,3,4-oxadiazol-2-ones 10 and 11, compounds 8 and 9 were reacted with 1,1'-carbonyldiimidazole (CDI). 


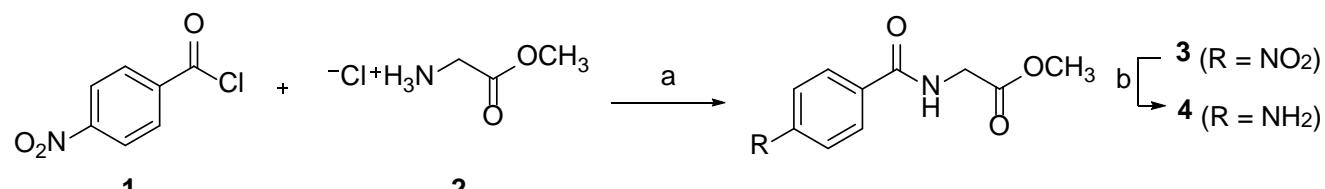

1

2
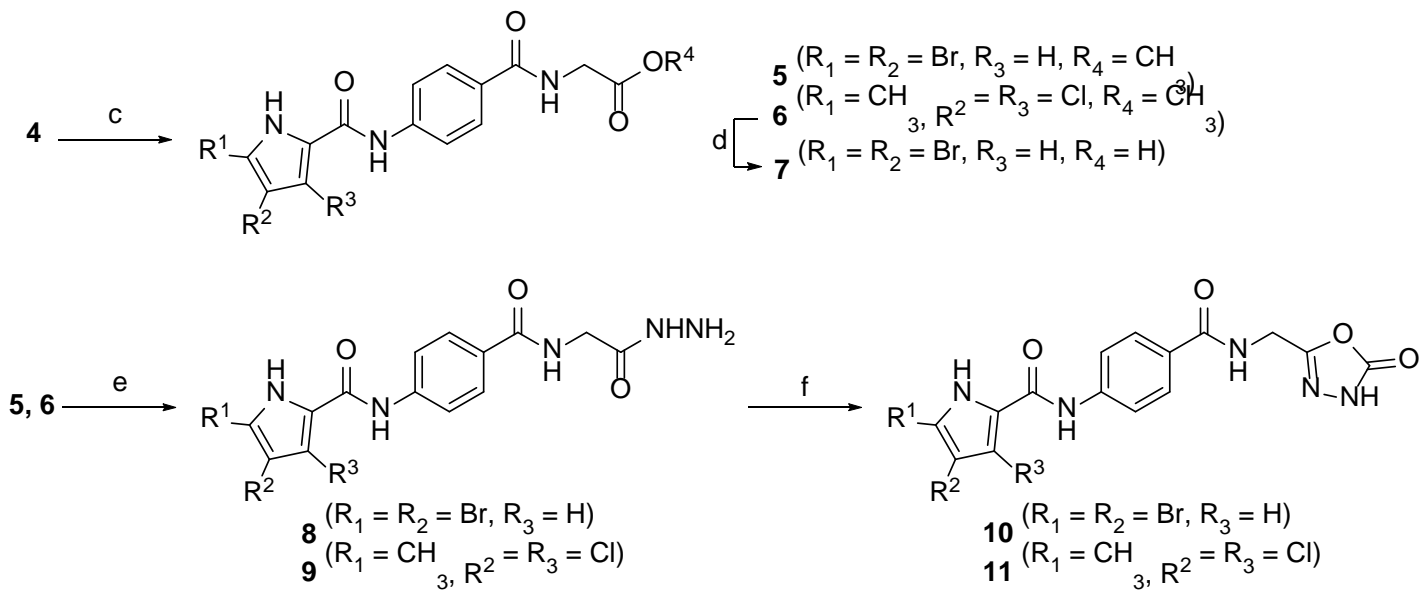

Scheme 1. Reagents and conditions: a) $\mathrm{K}_{2} \mathrm{CO}_{3}, \mathrm{CH}_{3} \mathrm{CN}, 0{ }^{\circ} \mathrm{C} \rightarrow \mathrm{rt}, 15 \mathrm{~h}$; b) $\mathrm{H}_{2}$, Pd-C, THF, $3 \mathrm{~h}$; c) 4,5-dibromopyrrole2-carboxylic acid, TBTU, NMM, $\mathrm{CH}_{2} \mathrm{Cl}_{2}, 50{ }^{\circ} \mathrm{C}, 15 \mathrm{~h}$ (for the synthesis of 5), i) 3,4-dichloro-5-methylpyrrole-2carboxylic acid, oxalyl chloride, $\mathrm{CH}_{2} \mathrm{Cl}_{2}$, rt, $15 \mathrm{~h}$, then ii) 4, pyridine, $\mathrm{CH}_{2} \mathrm{Cl}_{2}$, rt, $15 \mathrm{~h}$ (for the synthesis of 6); d) $1 \mathrm{M}$ $\mathrm{NaOH}$, THF, rt, 15 h; e) hydrazine monohydrate, EtOH, reflux, 15 h; f) CDI, 1,4-dioxane, $101{ }^{\circ} \mathrm{C}$, $15 \mathrm{~h}$ (for the synthesis of 10), CDI, DMF, $50^{\circ} \mathrm{C}, 15 \mathrm{~h}$ (for the synthesis of $\mathbf{1 1}$ ).

Type II compounds (19a-g, 20 and 21) were synthesized according to Scheme 2. First, methyl ester 13 was prepared from 3-hydroxy-4-nitrobenzoic acid (12) and thionyl chloride in methanol. The phenolic group of $\mathbf{1 3}$ was then alkylated with methyl (compound 14a), isopropyl (compound 14b) or benzyl (compound 14c) substituents. Compounds 14a and 14c were prepared using methyl iodide or benzyl bromide and potassium carbonate as base, while compound 14b was prepared using isopropanol under Mitsunobu conditions. Methyl esters 14a-c were hydrolyzed with $1 \mathrm{M}$ sodium hydroxide to give carboxylic acids 15a-c, which were subsequently coupled with glycine methyl ester hydrochloride to give compounds 16a-c, or with methyl 3-aminopropanoate to give compounds 16d-f. The nitro groups of 16a-f were reduced to amino groups by catalytic hydrogenation (for products 17a-b, 17d-e) or with tin(II) chloride (for products 17c and 17f). Pyrrolamides 18a-c were prepared by coupling 17a-b or 17d with 4,5-dibromopyrrole-2carboxylic acid using TBTU methodology, while pyrrolamides 18d-h were prepared from 17a-c or 17e-f and the corresponding pyrrole-2-carboxylic acid chloride prepared in situ using oxalyl 
chloride as reagent. Alkaline hydrolysis of compounds 18a-g gave the final products 19a-g, while hydrolysis of $\mathbf{1 8 h}$ was unsuccessful. Compound $18 \mathrm{~b}$ was additionally reacted with hydrazine monohydrate to give hydrazide 20, and, after heating 20 with CDI, the final product 21 was obtained.
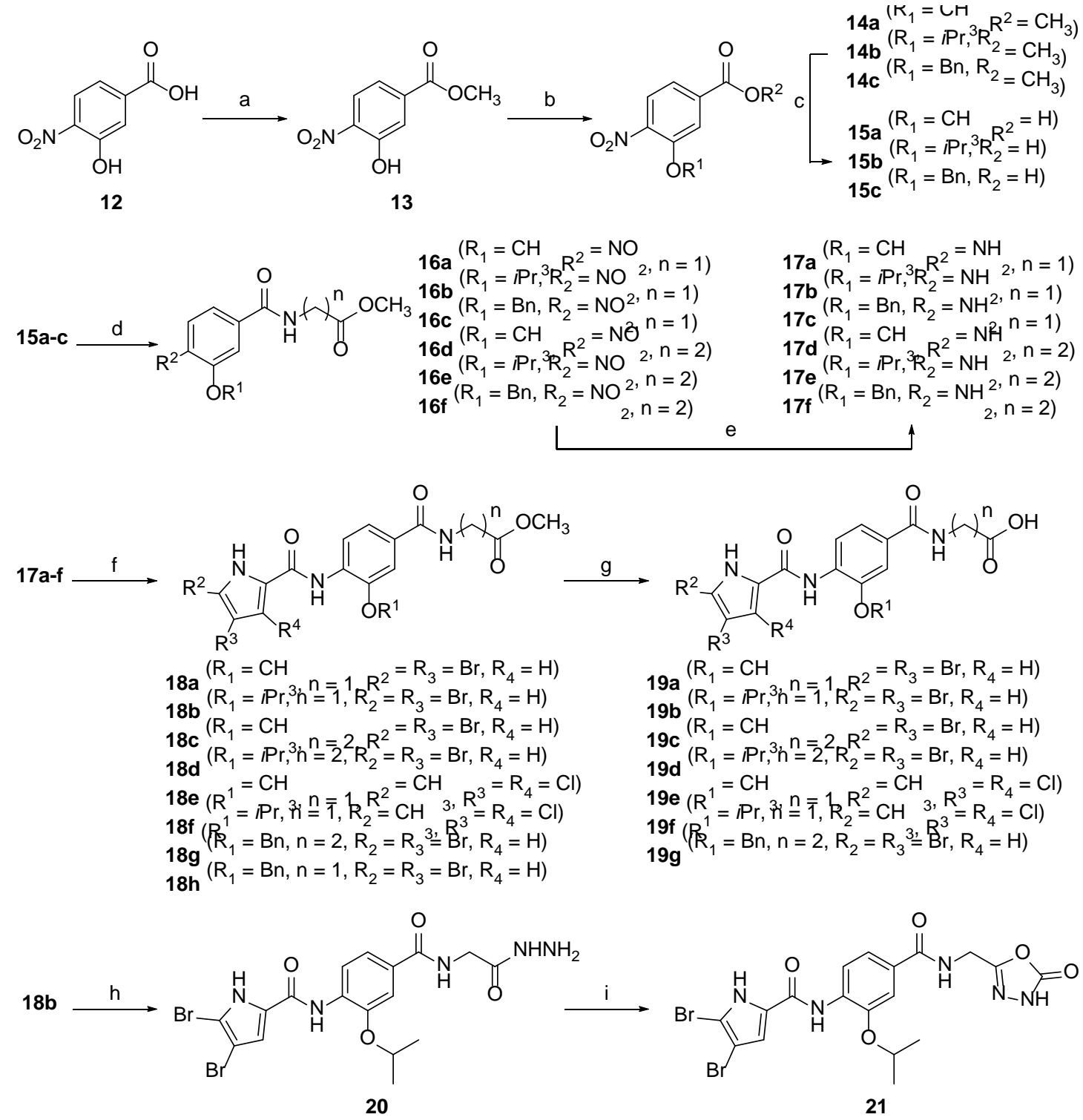

Scheme 2. Reagents and conditions: a) thionyl chloride, $\mathrm{MeOH}, 0{ }^{\circ} \mathrm{C} \rightarrow \mathrm{rt}, 15 \mathrm{~h}$; b) MeI, $\mathrm{K}_{2} \mathrm{CO}_{3}$, DMF, rt, $15 \mathrm{~h}$ (for the synthesis of 14a), isopropanol, triphenylphosphine, DIAD, THF, rt, $15 \mathrm{~h}$ (for the synthesis of $\mathbf{1 4 b}$ ), $\mathrm{K}_{2} \mathrm{CO}_{3}$, benzyl bromide, $\mathrm{CH}_{3} \mathrm{CN}$, rt $\rightarrow 60{ }^{\circ} \mathrm{C}, 3 \mathrm{~h}$ (for the synthesis of 14c); c) $1 \mathrm{M} \mathrm{NaOH}, \mathrm{MeOH}, \mathrm{rt}, 15 \mathrm{~h}$; d) glycine methyl ester hydrochloride (for the synthesis of 16a-c) or methyl 3-aminopropanoate (for the synthesis of 16d-f), TBTU, NMM, $\mathrm{CH}_{2} \mathrm{Cl}_{2}$, rt, 2-15 h; e) $\mathrm{H}_{2}$, Pd-C, MeOH, rt, 1-4 h (for the synthesis of 17a-b and 17d-e), $\mathrm{SnCl}_{2}, \mathrm{EtOAc}, \mathrm{EtOH}, 55{ }^{\circ} \mathrm{C}$, $24 \mathrm{~h}$ (for the synthesis of 17c and 17f); f) i) 4,5-dibromopyrrole-2-carboxylic acid, TBTU, $\mathrm{NMM}, \mathrm{CH}_{2} \mathrm{Cl}_{2}, \mathrm{rt}, 30 \mathrm{~min}$, 
then ii) 17a or $\mathbf{1 7 b}$ or $\mathbf{1 7 d}$, DMAP, $60^{\circ} \mathrm{C}, 15 \mathrm{~h}$ (for the synthesis of $\mathbf{1 8 a}-\mathbf{c}$ ), i) 4,5-dibromopyrrole-2-carboxylic acid, oxalyl chloride, $\mathrm{CH}_{2} \mathrm{Cl}_{2}$, rt, $15 \mathrm{~h}$, then ii) $\mathbf{1 7 c}$ or $\mathbf{1 7 e}$ or $\mathbf{1 7 f}$, pyridine, $\mathrm{CH}_{2} \mathrm{Cl}_{2}$, rt, $15 \mathrm{~h}$ (for the synthesis of $\mathbf{1 8 d}$ and 18g-h), i) 3,4-dichloro-5-methylpyrrole-2-carboxylic acid, oxalyl chloride, $\mathrm{CH}_{2} \mathrm{Cl}_{2}, \mathrm{rt}, 15 \mathrm{~h}$, then ii) 17a or 17b, pyridine, $\mathrm{CH}_{2} \mathrm{Cl}_{2}$, rt, $15 \mathrm{~h}$ (for the synthesis of 18e-f); g) 1-2 M NaOH, MeOH/THF, rt, $15 \mathrm{~h}$; h) hydrazine monohydrate, EtOH, reflux, 2 d; i) CDI, 1,4-dioxane, $101^{\circ} \mathrm{C}, 15 \mathrm{~h}$.

Compounds 25a-c and 29 were prepared according to Scheme 3. In the first step, the carboxylic acids 22a and 22b were converted to methyl esters using thionyl chloride and methanol. The obtained esters 23a and 23b were then coupled with 4,5-dibromopyrrole-2-carboxylic acid or with 3,4-dichloro-5-methylpyrrole-2-carboxylic acid, as described above, to give compounds 24a-d. The final products 25a-c were obtained after alkaline hydrolysis of methyl esters 24a-c. For the synthesis of compound 29, first, 4-nitrobenzoyl chloride (1) was reacted with methyl 4aminosalicylate (23b) in the presence of pyridine to give the amide 26. After reduction of the nitro group of compound 26 by catalytic hydrogenation, the obtained amine 27 was coupled with 4,5dibromopyrrole-2-carboxylic acid to give compound $\mathbf{2 8}$ which was submitted to alkaline hydrolysis to give the final compound 29. 

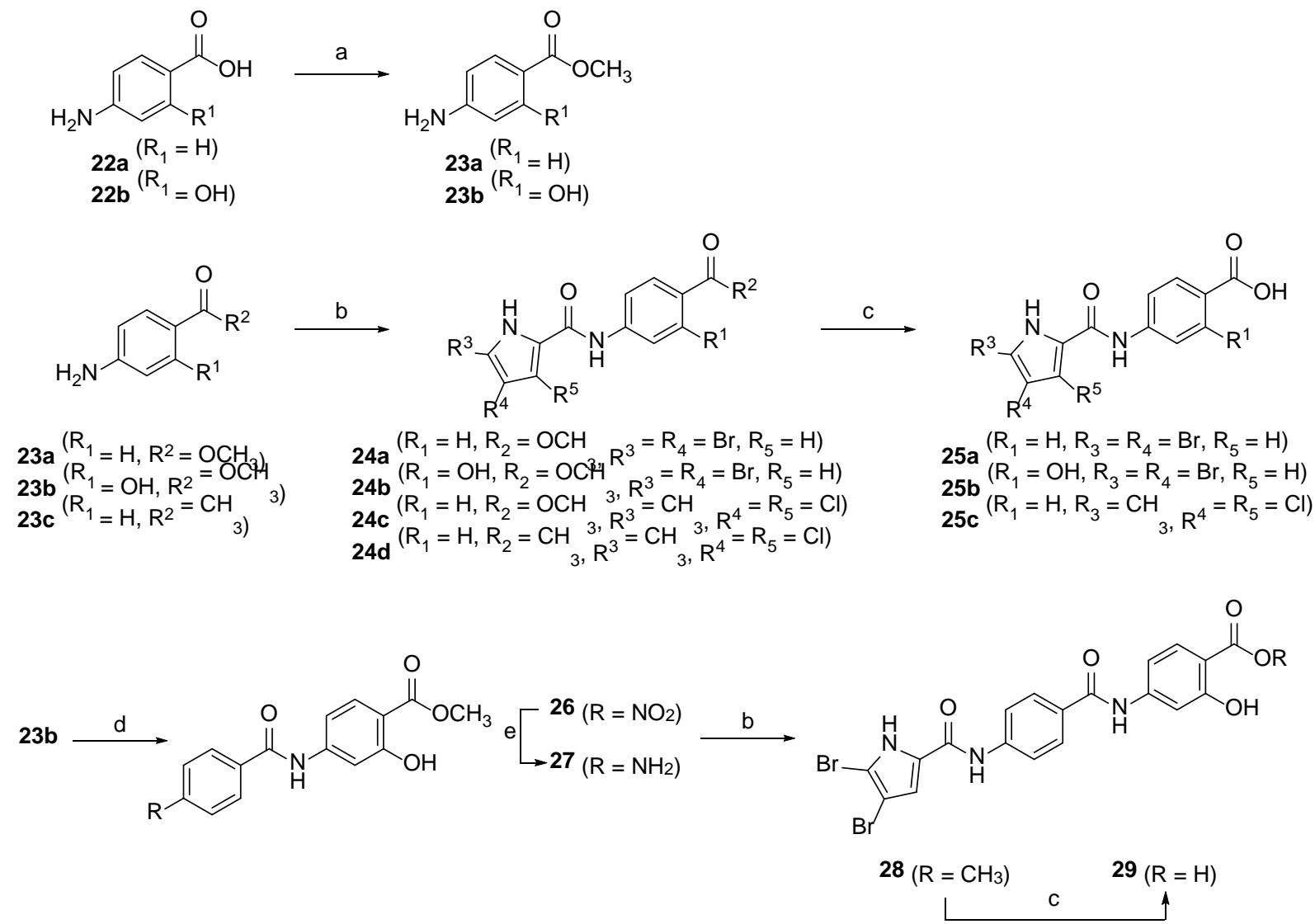

Scheme 3. Reagents and conditions: a) thionyl chloride, $\mathrm{MeOH}, 0{ }^{\circ} \mathrm{C} \rightarrow 70^{\circ} \mathrm{C}, 15 \mathrm{~h}$; b) i) 4,5-dibromopyrrole-2carboxylic acid (for the synthesis of 24a-b and 28) or 3,4-dichloro-5-methylpyrrole-2-carboxylic acid (for the synthesis of 24c-d), oxalyl chloride, $\mathrm{CH}_{2} \mathrm{Cl}_{2}$, rt, 15 h, then ii) 23a or $\mathbf{2 3 b}$ or $23 \mathrm{c}$ or $\mathbf{2 7}$, pyridine, $\mathrm{CH}_{2} \mathrm{Cl}_{2}$, rt, $15 \mathrm{~h}$; c) $1 \mathrm{M} \mathrm{NaOH}$, $\mathrm{MeOH} / \mathrm{THF}$, rt $\rightarrow 60^{\circ} \mathrm{C}, 30 \mathrm{~h}$ (for the synthesis of 25a-b and 29), $1 \mathrm{M} \mathrm{NaOH}$, THF, $45^{\circ} \mathrm{C}, 15 \mathrm{~h}$ (for the synthesis of 25c); d) 1, $\mathrm{CH}_{2} \mathrm{Cl}_{2}$, pyridine, rt 15 h; e) $\mathrm{H}_{2}$, Pd-C, MeOH/THF, rt, 3 h.

Inhibitory Activities against DNA Gyrase and Topoisomerase IV. Thirty-two new compounds were prepared and evaluated against E. coli DNA gyrase in a supercoiling inhibition assay. The results are presented in Tables 1-3 as residual activities (RA) of the enzyme in the presence of $10 \mu \mathrm{M}$ of compounds or as concentrations of compounds that inhibit the enzyme activity by $50 \%$ ( $\mathrm{IC}_{50}$ values). The most active compounds were additionally tested against topoisomerase IV from E. coli, and against DNA gyrase and topoisomerase IV from S. aureus.

In total, twelve compounds displayed $\mathrm{IC}_{50}$ values lower than $0.5 \mu \mathrm{M}$ against $E$. coli DNA gyrase, three of which $(\mathbf{1 1}, \mathbf{1 9 f}$ and $\mathbf{1 9 g})$ showed inhibitory activities in the low nanomolar range (IC s0 $_{<}$ $0.1 \mu \mathrm{M})$ and their enzymatic inhibition was thus better than that of novobiocin $\left(\mathrm{IC}_{50}=0.17 \mu \mathrm{M}\right)$. Generally, compounds containing 3,4-dichloro-5-methylpyrrole groups on the left-hand side of the 
molecules displayed higher activities against E. coli DNA gyrase than compounds containing 4,5dibromopyrrole moieties. For example, in the type I series, 3,4-dichloro-5-methylpyrrolamide 11 $\left(\mathrm{IC}_{50}=0.080 \mu \mathrm{M}\right)$ displayed a four-fold higher activity than its 4,5-dibromopyrrolamide analog 10 $\left(\mathrm{IC}_{50}=0.30 \mu \mathrm{M}\right)$. Similarly, compound $9\left(\mathrm{IC}_{50}=0.43 \mu \mathrm{M}\right)$ was five-times more active than its 4,5dibromopyrrolamide analog $8\left(\mathrm{IC}_{50}=2.4 \mu \mathrm{M}\right)$. Similar differences in activity could be observed between 4,5-dibromopyrrolamides and 3,4-dichloro-5-methylpyrrolamides of the type II (Table 2) and type III (Table 3) series. These results indicate that both pyrroles can occupy the hydrophobic binding pocket of the enzyme and form hydrophobic interactions with Val71, Val167, Val43 and Ala47, but the smaller methyl and chlorine atoms fit better into the enzyme's binding site. A further observation from Tables 1-3 is that compounds containing methyl ester groups on the right-hand side show weaker activities than their carboxylic acid counterparts, probably because they cannot form ionic interactions with Arg136. This can be seen by comparing the esters $6\left(\mathrm{IC}_{50}=0.41 \mu \mathrm{M}\right)$, 18a $\left(\mathrm{IC}_{50}=3.7 \mu \mathrm{M}\right)$ and $24 \mathbf{c}\left(\mathrm{IC}_{50}=1.6 \mu \mathrm{M}\right)$ on the one hand, with the corresponding carboxylic acids $7\left(\mathrm{IC}_{50}=0.28 \mu \mathrm{M}\right), 19 \mathrm{a}\left(\mathrm{IC}_{50}=0.31 \mu \mathrm{M}\right)$ and with $25 \mathrm{c}\left(\mathrm{IC}_{50}=0.79 \mu \mathrm{M}\right)$ on the other. When comparing the activities of compounds with carboxylic acid groups with their hydrazide analogs, the former were generally more active. For example, carboxylic acid $7\left(\mathrm{IC}_{50}=0.28 \mu \mathrm{M}\right)$ displayed greater activity than its hydrazide analogue $\mathbf{9}\left(\mathrm{IC}_{50}=0.43 \mu \mathrm{M}\right)$, compound $\mathbf{A}\left(\mathrm{IC}_{50}=0.45 \mu \mathrm{M}\right.$, reported previously) ${ }^{[15 \mathrm{~b}]}$ was more active than the corresponding hydrazide $8\left(\mathrm{IC}_{50}=2.4 \mu \mathrm{M}\right)$, and the carboxylic acid $19 b\left(\mathrm{IC}_{50}=0.16 \mu \mathrm{M}\right)$ was more potent than the hydrazide $20\left(\mathrm{IC}_{50}=1.6 \mu \mathrm{M}\right)$. These differences are, most probably, due to the loss of ionic interactions with Arg136 in the case of hydrazide groups.

There were no significant differences in activity between compounds that contain a carboxymethyl ( $\mathrm{n}=1$, Table 2$)$ and those containing the longer 2-carboxyethyl group $(\mathrm{n}=2$, Table 2) on the right-hand side of the molecules. Although, in the carboxylic acid subset (compounds 19a-g, Table 2), the carboxymethyl derivative $19 b\left(\mathrm{IC}_{50}=0.16 \mu \mathrm{M}\right)$ was slightly more active than the 2-carboxyethyl derivative $19 d\left(\mathrm{IC}_{50}=0.36 \mu \mathrm{M}\right), 19 \mathrm{a}\left(\mathrm{IC}_{50}=0.31 \mu \mathrm{M}\right)$ and 19c $\left(\mathrm{IC}_{50}=0.35\right.$ $\mu \mathrm{M}$ ) showed almost no difference in activities. Also, by observing the methyl ester subset compounds (18a-h, Table 2) the optimal length of the molecules could not be determined with certainty. These results can be due to the high flexibility of this side chain in solution, as recently proposed by molecular dynamics simulation. ${ }^{[14]}$ Probably both, the carboxymethyl and the 2- 
carboxyethyl groups can adopt conformations in which the terminal carboxylate group is either in contact with Arg136 or with the solvent.

With the introduction of methoxy (compounds 18a, 18e, 19a and 19e, Table 2), isopropoxy (compounds 18b, 18d, 18f, 19b, 19d, 19f, 20 and 21, Table 2) or benzyloxy substituents (compounds 18g, 18h and 19g, Table 2) at the 3-position of the central benzene ring, we intended to make additional contacts with the lipophilic floor of the enzyme. Among the 3,4-dichloro-5methylpyrrolamides, the most active was the isopropoxy compound 19f $\left(\mathrm{IC}_{50}=0.047 \mu \mathrm{M}\right)$, followed by the methoxy compound $19 e\left(\mathrm{IC}_{50}=0.12 \mu \mathrm{M}\right)$ and the unsubstituted compound 7 (IC 50 $=0.28 \mu \mathrm{M})$. In the 4,5-dibromopyrrolamide series the relationship was similar, as the isopropoxy compound 19b $\left(\mathrm{IC}_{50}=0.16 \mu \mathrm{M}\right)$ and the methoxy compound 19a $\left(\mathrm{IC}_{50}=0.31 \mu \mathrm{M}\right)$ were both more potent than the unsubstituted analog $\mathbf{A}\left(\mathrm{IC}_{50}=0.45 \mu \mathrm{M}\right)$. Even though the benzyloxy-substituted compound 18g $(\mathrm{RA}=21 \%)$ did not display significant activity, its carboxylic acid derivative 19g $\left(\mathrm{IC}_{50}=0.087 \mu \mathrm{M}\right)$ was among the most potent of the series. Overall, the results indicate that lipophilic substituents at the 3-position of the benzene ring are favorable for enhancing interactions with the enzyme.

With the type III series of compounds, we studied the influence of the $\mathrm{NH}\left(\mathrm{CH}_{2}\right)_{\mathrm{n}} \mathrm{COOR}$ group on the para position of the central aminobenzene ring (compounds 24a-d and 25a-c, Table 3). Some prepared compounds lacking the $\mathrm{NH}\left(\mathrm{CH}_{2}\right)_{\mathrm{n}} \mathrm{CO}$ linker showed good inhibitory activities, e.g. compound 24c had an IC 50 value of $1.6 \mu \mathrm{M}$ and its carboxylic acid analogue 25c an $\mathrm{IC}_{50}$ of 0.79 $\mu \mathrm{M}$ against $E$. coli DNA gyrase. These results are particularly interesting when taking into account the simple, fragment-like structures of these molecules that could still be optimized. Furthermore, two longer molecules, 28 and 29 (Table 3) have been prepared with an additional benzene ring, but their activities were weaker, probably because the terminal carboxylic acid group in these molecules is too far from Arg136 to form interactions.

Overall, the activities against $S$. aureus DNA gyrase, E. coli topoisomerase IV, and S. aureus topoisomerase IV were lower than those against E. coli DNA gyrase (Tables 1-3). The two compounds with the greatest activity against $S$. aureus DNA gyrase were $19 f$ with an $\mathrm{IC}_{50}$ of 2.3 $\mu \mathrm{M}$ and 19e with an $\mathrm{IC}_{50}$ of $4.1 \mu \mathrm{M}$. Six other compounds $(7,11,19 \mathrm{a}, 19 \mathrm{~b}, 19 \mathrm{~d}$ and $19 \mathrm{~g})$ displayed S. aureus DNA gyrase inhibitory activities in the low micromolar range, but none of the compounds have reached a comparable inhibition to that of novobiocin with an $\mathrm{IC}_{50}$ value of $41 \mathrm{nM}$. Seven of these compounds contained a free carboxylic acid group, which thus appears crucial for the activity. 
A possible reason for the weaker activities of compounds against $S$. aureus gyrase is that the adenine-binding pocket of this enzyme is slightly smaller than that of E. coli gyrase, which would indicate that smaller groups are more effective in binding to the hydrophobic binding site, as discussed recently. ${ }^{[15 b]}$ In line with this, the two most active compounds against $S$. aureus gyrase, 19e $\left(\mathrm{IC}_{50}=4.1 \mu \mathrm{M}\right)$ and $19 f\left(\mathrm{IC}_{50}=2.3 \mu \mathrm{M}\right)$, contain smaller 3,4-dichloro-5-methylpyrrole moieties, while the activities of their 4,5-dibromopyrrolamide analogs 19a $\left(\mathrm{IC}_{50}=17 \mu \mathrm{M}\right)$ and 19b $\left(\mathrm{IC}_{50}=22 \mu \mathrm{M}\right)$ were slightly lower. The most active compound against topoisomerase IV enzyme was again compound $\mathbf{1 9 f}$ with an $\mathrm{IC}_{50}$ values of $1.8 \mu \mathrm{M}$ against $E$. coli topo IV and $2.7 \mu \mathrm{M}$ against S. aureus topo IV. The weaker activities on E. coli topoisomerase IV than on E. coli DNA gyrase are probably due to the previously discussed differences in the binding sites of these enzymes. ${ }^{[15 b]}$

\begin{tabular}{|c|c|c|c|c|c|c|}
\hline \multirow[b]{2}{*}{ Compd } & \multirow[b]{2}{*}{$\mathrm{R}^{1}$} & \multirow[b]{2}{*}{$\mathrm{R}^{2}$} & \multicolumn{3}{|c|}{$\mathrm{IC}_{50}(\mu \mathrm{M})^{[\mathrm{a}]}$ or RA $(\%)^{[\mathrm{b}]}$} & \multirow[b]{2}{*}{$\begin{array}{c}\text { S. aureus } \\
\text { topo IV }\end{array}$} \\
\hline & & & $\begin{array}{l}\text { E. coli } \\
\text { gyrase }\end{array}$ & $\begin{array}{l}\text { S. aureus } \\
\text { gyrase }\end{array}$ & $\begin{array}{l}\text { E. coli } \\
\text { topo IV }\end{array}$ & \\
\hline 6 & 3,4-diCl-5-Me & COOMe & $\begin{array}{c}0.41 \pm 0.20 \\
\mu \mathrm{M}\end{array}$ & n.d. ${ }^{[c]}$ & n.d. & n.d. \\
\hline 7 & 3,4-diCl-5-Me & $\mathrm{COOH}$ & $\begin{array}{c}0.28 \pm 0.21 \\
\mu \mathrm{M}\end{array}$ & $11 \pm 0 \mu \mathrm{M}$ & $100 \%$ & $100 \%$ \\
\hline 8 & 4,5-diBr & $\mathrm{CONHNH}_{2}$ & $2.4 \pm 1.5 \mu \mathrm{M}$ & $93 \%$ & $79 \%$ & $95 \%$ \\
\hline 9 & 3,4-diCl-5-Me & $\mathrm{CONHNH}_{2}$ & $\begin{array}{c}0.43 \pm 0.26 \\
\mu \mathrm{M}\end{array}$ & $60 \%$ & $100 \%$ & $100 \%$ \\
\hline 10 & 4,5-diBr & $3^{3} N_{-N H}^{O}=0$ & $\begin{array}{c}0.30 \pm 0.09 \\
\mu \mathrm{M}\end{array}$ & $100 \%$ & $98 \%$ & $100 \%$ \\
\hline 11 & 3,4-diCl-5-Me & $\mathrm{N}_{-\mathrm{NH}}^{\mathrm{O}}=\mathrm{O}$ & $\begin{array}{c}0.080 \pm 0.027 \\
\mu \mathrm{M}\end{array}$ & $23 \pm 5 \mu \mathrm{M}$ & $100 \%$ & $62 \%$ \\
\hline \multicolumn{2}{|c|}{ novobiocin } & & $0.17 \mu \mathrm{M}$ & $0.041 \mu \mathrm{M}$ & $11 \mu \mathrm{M}$ & $27 \mu \mathrm{M}$ \\
\hline
\end{tabular}


Table 2. Inhibitory activities of type II compounds 18a-h, 19a-g, 20 and 21 against DNA gyrase and topoisomerase IV.<smiles></smiles>

\begin{tabular}{|c|c|c|c|c|c|c|c|c|}
\hline \multirow[b]{2}{*}{ Compd } & \multirow[b]{2}{*}{$\mathrm{R}^{1}$} & \multirow[b]{2}{*}{$\mathrm{R}^{2}$} & \multirow[b]{2}{*}{$\mathrm{R}^{3}$} & \multirow[b]{2}{*}{$\mathrm{n}$} & \multicolumn{4}{|c|}{$\mathrm{IC}_{50}(\mu \mathrm{M})^{[\mathrm{a}]}$ or $\mathrm{RA}(\%)^{[\mathrm{b}]}$} \\
\hline & & & & & $\begin{array}{l}\text { E. coli } \\
\text { gyrase }\end{array}$ & $\begin{array}{l}\text { S. aureus } \\
\text { gyrase }\end{array}$ & $\begin{array}{l}\text { E. coli } \\
\text { topo IV }\end{array}$ & $\begin{array}{l}\text { S. aureus } \\
\text { topo IV }\end{array}$ \\
\hline $18 a$ & 4,5-diBr & $\mathrm{Me}$ & COOMe & 1 & $3.7 \pm 2.1 \mu \mathrm{M}$ & n.d. ${ }^{[\mathrm{c}]}$ & n.d. & n.d. \\
\hline $18 b$ & 4,5-diBr & $i \mathrm{Pr}$ & COOMe & 1 & $97 \%$ & n.d. & n.d. & n.d. \\
\hline $18 c$ & 4,5-diBr & $\mathrm{Me}$ & COOMe & 2 & $4.2 \pm 0.3 \mu \mathrm{M}$ & n.d. & n.d. & n.d. \\
\hline 18d & 4,5-diBr & $i \mathrm{Pr}$ & COOMe & 2 & $3.9 \pm 0.8 \mu \mathrm{M}$ & n.d. & n.d. & n.d. \\
\hline $18 \mathrm{e}$ & 3,4-diCl-5-Me & $\mathrm{Me}$ & COOMe & 1 & $\begin{array}{c}0.54 \pm 0.36 \\
\mu \mathrm{M}\end{array}$ & $99 \%$ & $100 \%$ & $100 \%$ \\
\hline $18 f$ & 3,4-diCl-5-Me & $i \mathrm{Pr}$ & COOMe & 1 & $2.3 \pm 0.1 \mu \mathrm{M}$ & n.d. & n.d. & n.d. \\
\hline $18 g$ & 4,5-diBr & Bzl & COOMe & 2 & $21 \%$ & n.d. & n.d. & n.d. \\
\hline $18 \mathrm{~h}$ & 4,5-diBr & Bzl & COOMe & 1 & $77 \%$ & n.d. & n.d. & n.d. \\
\hline 19a & 4,5-diBr & $\mathrm{Me}$ & $\mathrm{COOH}$ & 1 & $\begin{array}{c}0.31 \pm 0.11 \\
\mu \mathrm{M}\end{array}$ & $17 \pm 2 \mu \mathrm{M}$ & $85 \%$ & $96 \%$ \\
\hline $19 b$ & 4,5-diBr & iPr & $\mathrm{COOH}$ & 1 & $\begin{array}{c}0.16 \pm 0.06 \\
\mu \mathrm{M}\end{array}$ & $22 \pm 4 \mu \mathrm{M}$ & $5.0 \pm 5.2 \mu \mathrm{M}$ & $13 \pm 10 \mu \mathrm{M}$ \\
\hline $19 c$ & 4,5-diBr & $\mathrm{Me}$ & $\mathrm{COOH}$ & 2 & $\begin{array}{c}0.35 \pm 0.10 \\
\mu \mathrm{M}\end{array}$ & $67 \%$ & $100 \%$ & $98 \%$ \\
\hline 19d & 4,5-diBr & $i \operatorname{Pr}$ & $\mathrm{COOH}$ & 2 & $\begin{array}{c}0.36 \pm 0.29 \\
\mu \mathrm{M}\end{array}$ & $28 \pm 10 \mu \mathrm{M}$ & $76 \%$ & $90 \%$ \\
\hline $19 e$ & 3,4-diCl-5-Me & $\mathrm{Me}$ & $\mathrm{COOH}$ & 1 & $\begin{array}{c}0.12 \pm 0.10 \\
\mu \mathrm{M}\end{array}$ & $\begin{array}{c}4.1 \pm 2.9 \\
\mu \mathrm{M}\end{array}$ & $99 \%$ & $65 \%$ \\
\hline $19 f$ & 3,4-diCl-5-Me & $i \mathrm{Pr}$ & $\mathrm{COOH}$ & 1 & $\begin{array}{c}0.047 \pm 0.021 \\
\mu \mathrm{M}\end{array}$ & $\begin{array}{c}2.3 \pm 0.5 \\
\mu \mathrm{M}\end{array}$ & $1.4 \pm 0.5 \mu \mathrm{M}$ & $2.3 \pm 0.7 \mu \mathrm{M}$ \\
\hline $19 \mathrm{~g}$ & 4,5-diBr & Bzl & $\mathrm{COOH}$ & 2 & $\begin{array}{c}0.087 \pm 0.052 \\
\mu \mathrm{M}\end{array}$ & $20 \pm 5 \mu \mathrm{M}$ & $100 \%$ & $98 \%$ \\
\hline 20 & 4,5-diBr & $i \mathrm{Pr}$ & $\mathrm{CONHNH}_{2}$ & 1 & $1.6 \pm 0.0 \mu \mathrm{M}$ & n.d. & n.d. & n.d. \\
\hline 21 & 4,5-diBr & $i \mathrm{Pr}$ & $\sqrt{-N H}=0$ & 1 & $1.7 \pm 0.0 \mu \mathrm{M}$ & $65 \%$ & $100 \%$ & $99 \%$ \\
\hline novobio & & & & & $0.17 \mu \mathrm{M}$ & $0.041 \mu \mathrm{M}$ & $11 \mu \mathrm{M}$ & $27 \mu \mathrm{M}$ \\
\hline
\end{tabular}




\begin{tabular}{|c|c|c|c|c|c|c|c|}
\hline \multirow[b]{2}{*}{ Compd } & \multirow[b]{2}{*}{$\mathrm{R}^{1}$} & \multirow[b]{2}{*}{$\mathrm{R}^{2}$} & \multirow[b]{2}{*}{$\mathrm{R}^{3}$} & \multicolumn{3}{|c|}{$\mathrm{IC}_{50}(\mu \mathrm{M})^{[\mathrm{a}]}$ or RA $(\%)^{[\mathrm{b}]}$} & \multirow[b]{2}{*}{$\begin{array}{c}\text { S. aureus } \\
\text { topo IV }\end{array}$} \\
\hline & & & & $\begin{array}{l}\text { E. coli } \\
\text { gyrase }\end{array}$ & $\begin{array}{l}\text { S. aureus } \\
\text { gyrase }\end{array}$ & $\begin{array}{l}\text { E. coli } \\
\text { topo IV }\end{array}$ & \\
\hline $24 a$ & 4,5-diBr & $\mathrm{H}$ & $\mathrm{OMe}$ & $5.8 \pm 1.7 \mu \mathrm{M}$ & n.d. ${ }^{[c]}$ & n.d. & n.d. \\
\hline $24 b$ & 4,5-diBr & $\mathrm{OH}$ & $\mathrm{OMe}$ & $94 \%$ & n.d. & n.d. & n.d. \\
\hline $24 c$ & 3,4-diCl-5-Me & $\mathrm{H}$ & $\mathrm{OMe}$ & $1.6 \pm 0.5 \mu \mathrm{M}$ & $100 \%$ & $94 \%$ & $100 \%$ \\
\hline 24d & 3,4-diCl-5-Me & $\mathrm{H}$ & $\mathrm{Me}$ & $\begin{array}{c}0.72 \pm 0.09 \\
\mu \mathrm{M}\end{array}$ & $100 \%$ & $100 \%$ & $100 \%$ \\
\hline $25 a$ & 4,5-diBr & $\mathrm{H}$ & $\mathrm{OH}$ & $2.9 \pm 0.4 \mu \mathrm{M}$ & n.d. & n.d. & n.d. \\
\hline $25 b$ & 4,5-diBr & $\mathrm{OH}$ & $\mathrm{OH}$ & $2.7 \pm 0.1 \mu \mathrm{M}$ & n.d. & n.d. & n.d. \\
\hline $25 c$ & 3,4-diCl-5-Me & $\mathrm{H}$ & $\mathrm{OH}$ & $\begin{array}{c}0.79 \pm 0.02 \\
\mu \mathrm{M}\end{array}$ & $62 \%$ & $11 \pm 2 \mu \mathrm{M}$ & $45 \pm 4 \mu \mathrm{M}$ \\
\hline 28 & 4,5-diBr & $\mathrm{H}$ & $\begin{array}{l}\text { 4-NH-2-OH- } \\
\left(\mathrm{C}_{6} \mathrm{H}_{3}\right)-\mathrm{COCH}_{3}\end{array}$ & $80 \%$ & n.d. & n.d. & n.d. \\
\hline 29 & 4,5-diBr & $\mathrm{H}$ & $\begin{array}{l}\text { 4-NH-2-OH- } \\
\left(\mathrm{C}_{6} \mathrm{H}_{3}\right)-\mathrm{COOH}\end{array}$ & $\begin{array}{c}0.60 \pm 0.37 \\
\mu \mathrm{M}\end{array}$ & n.d. & n.d. & n.d. \\
\hline \multicolumn{2}{|c|}{ novobiocin } & & & $0.17 \mu \mathrm{M}$ & $0.041 \mu \mathrm{M}$ & $11 \mu \mathrm{M}$ & $27 \mu \mathrm{M}$ \\
\hline
\end{tabular}

Antibacterial Activity. Compounds were evaluated against two Gram-positive (S. aureus ATCC 25923 and Enterococcus faecalis ATCC 29212) and two Gram-negative (E. coli ATCC 25922 and Pseudomonas aeruginosa ATCC 27853) wild type bacterial strains at $50 \mu \mathrm{M}$ concentration. Results are presented in Table 1S (Supporting information) as percent inhibition of growth after $24 \mathrm{~h}$ incubation. In general, the activities against Gram-positive bacteria were greater than those against Gram-negative bacteria. This could be due to difficulties in permeation of compounds through the Gram-negative bacterial cell wall, or to efflux of inhibitors from the bacteria. In total, nine compounds $(6,9,11,18 f, 19 f, 19 g, 21,25 c$ and 29) inhibited the growth of Gram-positive E. faecalis by more than $50 \%$ at $50 \mu \mathrm{M}$ concentration, four of which $\mathbf{( 6 , 1 1 , 1 9 f}$ and 25c) displayed more than 70\% inhibition of growth. Compound 11 also showed 64\% inhibition of growth of S. aureus and 51\% inhibition of growth of Gram-negative E. coli (Table 1S). The results 
of the minimum inhibitory concentration (MIC) experiments against S. aureus, E. faecalis and E. coli for the most interesting compounds are presented in Table 4. The MIC values for compounds 11 and 19f against $E$. faecalis were $12.5 \mu \mathrm{M}$ and $50 \mu \mathrm{M}$ (MIC for ciprofloxacin $=3.02 \mu \mathrm{M})$. The MIC value for compound 11 against S. aureus was $75 \mu \mathrm{M}(\mathrm{MIC}$ for ciprofloxacin $=1.51 \mu \mathrm{M})$. With other tested compounds, the MIC level ( $\geq 90 \%$ inhibition) was not reached even at the highest concentration of $125 \mu \mathrm{M}$ (Table 4). The highest antibacterial activity of compound $\mathbf{1 1}$ is in line with our design strategy, that the bioisosteric replacement of the terminal carboxylic acid group with the 1,3,4-oxadiazol-2-one ring might lead to easier entry of inhibitors into the bacterial cell due to their lower acidity and polarity.

\begin{tabular}{|c|c|c|c|}
\hline \multirow{2}{*}{ Compd } & \multicolumn{3}{|c|}{$\operatorname{MIC}(\mu \mathrm{M})^{[\mathrm{a}]}$} \\
\hline & S. aureus (ATCC 25923) & E. faecalis (ATCC 29212) & E. coli (ATCC 25922) \\
\hline 6 & n.d..$^{[b]}$ & $>125$ & n.d. \\
\hline 11 & 75 & 12.5 & $>125$ \\
\hline $19 f$ & n.d. & 50 & n.d. \\
\hline $19 g$ & $>125$ & $>125$ & n.d. \\
\hline 21 & $>125$ & $>125$ & n.d. \\
\hline $25 c$ & n.d. & $>125$ & n.d. \\
\hline 29 & n.d. & $>125$ & n.d. \\
\hline
\end{tabular}

Fifteen compounds (6, 7, 9, 11, 18f, 19f, 24a-d, 25a, 25b, 25c, 28 and 29) were additionally tested against two E. coli mutant strains, JD17464 and JW5503. E. coli JD17464 is an IpxC deletion mutant with impaired outer membrane, while E. coli JW5503 is a tolC deletion mutant with a defective efflux pump. Inhibition of growth was measured at $50 \mu \mathrm{M}$ concentration of compounds after 24 h incubation (Table 2S). MIC values for six selected compounds $(\mathbf{6}, \mathbf{9}, \mathbf{1 1}, \mathbf{1 9 f}, \mathbf{2 4 a}$ and 25c) against E. coli JW5503 are presented in Table 5. The activities against the mutant with impaired outer membrane (JD17464) were comparable with those against wild type E. coli. On the other hand, activities against the mutant with a defective efflux pump (JW5503) were greater for the majority of the tested compounds. The most active compound was oxadiazolone $\mathbf{1 1}$ with an 
MIC value of $6.25 \mu \mathrm{M}$, followed by a type III compound 25c with $25 \mu \mathrm{M}$ MIC. Compounds 6, 9, 19f and 24a had an MIC of $50 \mu \mathrm{M}$. These results indicate that the efflux of inhibitors is probably the major factor causing the lower activities of these compounds against the Gram-negative bacteria. To confirm these findings, compounds $\mathbf{6 , 9}, \mathbf{1 1}, \mathbf{1 9 f}$ and $25 \mathrm{c}$ were additionally evaluated against wild type E. coli in the presence of $100 \mu \mathrm{g} / \mathrm{mL}$ concentration of efflux inhibitor phenylalanine-arginine $\beta$-naphthylamide $(\mathrm{PA} \beta \mathrm{N})^{[19]}$ (Table 5). The most active compound was again compound 11, with an MIC of $3.13 \mu \mathrm{M}$, followed by 25c with an MIC of $12.5 \mu \mathrm{M}$, and compounds $6(\mathrm{MIC}=25 \mu \mathrm{M}), \mathbf{1 9 f}(\mathrm{MIC}=25 \mu \mathrm{M})$ and $9(\mathrm{MIC}=50 \mu \mathrm{M})$. Observing the inhibitory activity of compound $\mathbf{1 1}$ against wild type $E$. coli with and without PA $\beta \mathrm{N}$ at different time-points (4, 8 and 24 h) clearly demonstrates that this compound is able to affect the growth in the logarithmic growth phase also without PA $\beta N$, but that at the 24 h end-point the inhibitory activity no longer reaches the MIC (Figure 1S). In the presence of PA $\beta N$, stronger inhibition is seen at all time points. These results confirm that, in Gram-negative bacteria, the prepared compounds are most probably substrates for efflux pumps, which should be taken into account in the design of all future series of $N$-phenylpyrrolamide inhibitors. As has been demonstrated for the pyrrolopyrimidine series of DNA gyrase inhibitors, ${ }^{[9]}$ despite the susceptibility to efflux, it is nevertheless possible to achieve good MICs against Gram-negative bacteria.

\begin{tabular}{|c|c|c|}
\hline \multirow{2}{*}{ Compd } & \multicolumn{2}{|c|}{$\operatorname{MIC}(\mu \mathrm{M})^{[\mathrm{a}]}$} \\
\hline & E. coli $(\mathrm{JW} 5503)^{[\mathrm{b}]}$ & E. coli (ATCC 25922) with $\mathrm{Pa} \beta \mathrm{N}^{[c]}$ \\
\hline 6 & 50 & 25 \\
\hline 9 & 50 & 50 \\
\hline 11 & 6.25 & 3.13 \\
\hline $19 f$ & 50 & 25 \\
\hline $24 \mathbf{a}$ & 50 & n.d. ${ }^{[\mathrm{d}]}$ \\
\hline 25c & 25 & 12.5 \\
\hline \multicolumn{3}{|c|}{$\begin{array}{l}\text { [a] MIC = minimum inhibitory concentration that inhibited the growth of } \\
\text { bacteria by } \geq 90 \% \text {. Ciprofloxacin was used as a positive control. [b] E. coli } \\
\text { tolC deletion mutant with defective efflux pump. [c] Phenylalanine-arginine } \beta \text { - } \\
\text { naphthylamide; an efflux pump inhibitor. The tests were performed in the } \\
\text { presence of } 100 \mu \mathrm{g} / \mathrm{mL} \text { concentration of PA } \beta \mathrm{N} \text {. [d] Not determined. }\end{array}$} \\
\hline
\end{tabular}




\section{CONCLUSION}

Despite the huge amount of research work, there are currently no inhibitors of the ATPase activities of DNA gyrase and/or topoisomerase IV in clinical use. To optimise and further develop the promising class of $\mathrm{N}$-phenylpyrrolamide DNA gyrase B inhibitors, we have designed and prepared thirty-two new compounds of this class and evaluated their activities against DNA gyrase and topoisomerase IV from E. coli and S. aureus. The most potent compounds, 11, 19f and 19g, had $\mathrm{IC}_{50}$ values against $E$. coli DNA gyrase in the low nanomolar range $\left(\mathrm{IC}_{50}<100 \mathrm{nM}\right.$ ). The activities against DNA gyrase from S. aureus and against topoisomerase IV were lower. The most potent compound, 11, had an MIC value of $12.5 \mu \mathrm{M}$ against Gram-positive E. faecalis. Even though the activities against wild type Gram-negative $E$. coli were lower, interesting results were obtained against the efflux pump deficient and against the wild type $E$. coli strains in the presence of efflux pump inhibitor PA $\beta \mathrm{N}$, where the MICs of compound 11 were $6.25 \mu \mathrm{M}$ and $3.13 \mu \mathrm{M}$, respectively. These results indicate that major factor responsible for the lower activity of this type of compounds against the Gram-negative bacteria is their efflux from the cells. These results should be taken into account in the design of future series of this class of GyrB inhibitors.

\section{EXPERIMENTAL SECTION}

Determination of Inhibitory Activities on E. coli and S. aureus DNA Gyrase. Inhibitory activities were determined in an assay from Inspiralis on streptavidin-coated 96-well microtiter plates from Thermo scientific Pierce. First, the plates were rehydrated with buffer ( $20 \mathrm{mM}$ Tris$\mathrm{HCl}$ with $\mathrm{pH}$ 7.6, $0.01 \% \mathrm{w} / \mathrm{v} \mathrm{BSA}, 0.05 \% \mathrm{v} / \mathrm{v}$ Tween $20,137 \mathrm{mM} \mathrm{NaCl}$ ) and the biotinylated oligonucleotide was then immobilized. After washing off the unbound oligonucleotide, the enzyme test was performed. The reaction volume of $30 \mu \mathrm{L}$ in buffer $(35 \mathrm{mM}$ Tris $\times \mathrm{HCl}$ with $\mathrm{pH} 7.5,4 \mathrm{mM}$ $\mathrm{MgCl}_{2}, 24 \mathrm{mM} \mathrm{KCl}, 2 \mathrm{mM}$ DTT, $1.8 \mathrm{mM}$ spermidine, $1 \mathrm{mM}$ ATP, 6.5 \% w/v glycerol, $0.1 \mathrm{mg} / \mathrm{mL}$ albumin) contained $1.5 \mathrm{U}$ of DNA gyrase from E. coli or S. aureus, $0.75 \mu \mathrm{g}$ of relaxed pNO1 plasmid, and $3 \mu \mathrm{L}$ solution of the inhibitor in $10 \%$ DMSO and $0.008 \%$ Tween 20 . Reaction solutions were incubated at $37^{\circ} \mathrm{C}$ for $30 \mathrm{~min}$. After that, the TF buffer ( $50 \mathrm{mM} \mathrm{NaOAc}$ with $\mathrm{pH}$ 5.0, $50 \mathrm{mM} \mathrm{NaCl}$ and $50 \mathrm{mM} \mathrm{MgCl}_{2}$ ) was added to terminate the enzymatic reaction. After additional incubation for $30 \mathrm{~min}$ at $\mathrm{rt}$, during which biotin-oligonucleotide-plasmid triplex was formed, the unbound plasmid was washed off using TF buffer and SybrGOLD in T10 buffer (10 
mM Tris $\mathrm{HCl}$ with $\mathrm{pH} 8.0$ and 1 mM EDTA) was added. The fluorescence was measured with a microplate reader (BioTek Synergy H4, excitation: 485 nm, emission: $535 \mathrm{~nm}$ ). Initial screening was done at 100 or $10 \mu \mathrm{M}$ concentration of inhibitors. For the most active inhibitors IC 50 was determined using seven concentrations of tested compounds. GraphPad Prism software was used to calculate the $\mathrm{IC}_{50}$ values. The result is given as the average value of three independent measurements. As the internal standard novobiocin ( $\mathrm{IC}_{50}=0.168 \mu \mathrm{M}$ (lit. ${ }^{[20]} 0.08 \mu \mathrm{M}$ ) for E. coli gyrase and $\mathrm{IC}_{50}=0.041 \mu \mathrm{M}$ (lit. ${ }^{[20]} 0.01 \mu \mathrm{M}$ ) for $S$. aureus gyrase) was used.

Determination of Inhibitory Activities on $\boldsymbol{E}$. coli and $\boldsymbol{S}$. aureus Topoisomerase IV. IC 50 values were determined in an assay from Inspiralis on streptavidin-coated 96-well microtiter plates from Thermo scientific Pierce. First, the plates were rehydrated with buffer (20 mM Tris-HCl with $\mathrm{pH}$ 7.6, 0.01\% w/v BSA, 0.05\% v/v Tween 20, $137 \mathrm{mM} \mathrm{NaCl}$ ) and biotinylated oligonucleotide was then immobilized. After washing off the unbound oligonucleotide, the enzyme test was performed. The reaction volume of $30 \mu \mathrm{L}$ in buffer (40 mM HEPES KOH with pH 7.6, $100 \mathrm{mM}$ potassium glutamate, $10 \mathrm{mM}$ magnesium acetate, $10 \mathrm{mM}$ DTT, $1 \mathrm{mM}$ ATP, $0.05 \mathrm{mg} / \mathrm{mL}$ albumin) contained $1.5 \mathrm{U}$ of topoisomerase IV from E. coli or $S$. aureus, $0.75 \mu \mathrm{g}$ of pNO1 supercoiled plasmid, and $3 \mu \mathrm{L}$ solution of the inhibitor in DMSO (10\%) and Tween 20 (0.008\%). Reaction mixtures were incubated at $37^{\circ} \mathrm{C}$ for $30 \mathrm{~min}$ and after that, the TF buffer (50 mM NaOAc with pH 5.0, $50 \mathrm{mM} \mathrm{NaCl}$ and $50 \mathrm{mM} \mathrm{MgCl}_{2}$ ) was added to terminate the enzymatic reaction. After additional incubation for 30 min at rt, during which triplex (biotin-oligonucleotide-plasmid) was formed, the unbound plasmid was washed off using TF buffer and SybrGOLD in T10 buffer (10 mM Tris $\mathrm{HCl}$ with pH 8.0 and 1 mM EDTA) was added. The fluorescence was measured with a microplate reader (BioTek Synergy H4, excitation: $485 \mathrm{~nm}$, emission: $535 \mathrm{~nm}$ ). Initial screening was done at 100 or $10 \mu \mathrm{M}$ concentration of inhibitors. For the most active inhibitors $\mathrm{IC}_{50}$ was determined using seven concentrations of tested compounds. GraphPad Prism software was used to calculate the $\mathrm{IC}_{50}$ values. The result is given as the average value of three independent measurements. As the internal standard novobiocin ( $\mathrm{IC}_{50}=11.1 \mu \mathrm{M}$ (lit. $\left.{ }^{[20]} 10 \mu \mathrm{M}\right)$ for E. coli topoisomerase IV and $\mathrm{IC}_{50}=26.7 \mu \mathrm{M}$ (lit. ${ }^{[20]} 20 \mu \mathrm{M}$ ) for S. aureus topoisomerase IV) was used.

Determination of Antibacterial Activity. Clinical microbiology control strains of Enterococcus faecalis (ATCC 29212), Escherichia coli (ATCC 25922), Pseudomonas aeruginosa (ATCC 27853), and Staphylococcus aureus (ATCC 25923) were obtained from Microbiologics Inc. (St. Cloud, Minnesota, USA). Single-gene knock-out mutant strains of E. coli, JW5503 (tolC knock- 
out ${ }^{[21]}$ and JD17464 (IpxC knock-out), were obtained from the NBRP-E.coli collection at the National Institute of Genetics (NIG, Japan). To determine antibacterial activity, broth microdilution assays in 96-well plates were carried out by following the CLSI guidelines. ${ }^{[22]}$ For selected compounds minimum inhibitory concentrations (MIC) were determined by dose-response experiments (reported values are from at least two independent experiments, each with three replicates per concentration). In the experiments with the efflux inhibitor, the assay media was supplemented with $100 \mu \mathrm{g} / \mathrm{mL}$ of Phe-Arg- $\beta$-naphthylamide (PA $\beta N$; Sigma-Aldrich, Switzerland).

\section{Molecular Modeling.}

Protein and Ligand Preparation. 3D compound models were built using ChemBio3D Ultra 16.0. ${ }^{[23]}$ MMFF94 force field ${ }^{[24]}$ was used for the optimization of geometries and partial atomic charges were added. Energy was minimized to less than $0.001 \mathrm{kcal} /(\mathrm{mol} \AA$ ) gradient value. The structure was refined with GAMESS interface using PM3 method, QA optimization algorithm and Gasteiger Hückel charges for all atoms for 100 steps. ${ }^{[23]}$ GOLD Suite v5.4 ${ }^{[25][26]}$ was used for molecular docking calculations. GOLD graphical user interface was used for receptor preparation. To the protein hydrogen atoms were added and correct tautomers and protonation states were assigned. Except for HOH614, all water molecules and ligands were deleted from the crystal structure. Amino acid residues within $7 \AA$ around the ligand (PDB entry: 4DUH ${ }^{[18]}$ ) were selected as the binding site.

Ligand Docking. Compounds were docked to the defined binding site in 25 independent genetic algorithm (GA) runs by applying different GA parameters (population size $=100$, selection pressure $=1.1$, number of operations $=100,000$, niche size $=2$, number of islands $=5$, mutation frequency $=95$, crossover frequency $=95$, migration frequency $=10$ ) and scoring functions (GoldScore, ChemScore, CHEMPLP). The most representative results were obtained using GoldScore as a scoring function. Ligands with RMSD value less than $1.5 \AA$ were joined in clusters and early termination was allowed if the top 3 solutions were within $1.0 \AA$ of the RMSD value. Proposed binding modes of the top 5 highest scored docking poses were evaluated for each ligand and used for graphical representation in PyMOL. ${ }^{\text {[27] }}$

Chemistry. Chemicals were obtained from Apollo Scientific (Stockport, UK), Sigma-Aldrich (St. Louis, MO, USA) and Acros Organics (Geel, Belgium). TLC analyses were performed on Merck $60 \mathrm{~F}_{254}$ plates $(0.25 \mathrm{~mm})$. Flash column chromatography was performed on silica gel 60 (particle size 240-400 mesh). For HPLC analyses an Agilent Technologies 1100 instrument 
(Agilent Technologies, CA, USA) with a G1313A autosampler, a G1316A thermostat and a G1365B UV-Vis detector was used. An Agilent Eclipse Plus C18 column was used (5 $\mu \mathrm{m}, 4.6 \times$ $150 \mathrm{~mm}$ ) with a flow rate of $1.0 \mathrm{~mL} / \mathrm{min}$. Melting points were determined on a hot-stage microscope from Reichert and are uncorrected. ${ }^{1} \mathrm{H}$ and ${ }^{13} \mathrm{C}$ NMR spectra were recorded at 400 and $100 \mathrm{MHz}$ on a Bruker AVANCE III 400 spectrometer (Bruker Corporation, MA, USA) as $\left[\mathrm{D}_{6}\right] \mathrm{DMSO}$ or $\mathrm{CDCl}_{3}$ solutions. For the IR measurements, a Thermo Nicolet Nexus 470 ESP FTIR spectrometer (Thermo Fisher Scientific, MA, USA) was used. Mass spectra were recorded on an Advion CMS spectrometer (Advion Inc., Ithaca, USA) or VG Analytical Autospec Q mass spectrometer (Fisons, VG Analytical, Manchester, UK). All tested compounds were more than 95\% pure as established by HPLC.

\section{Synthetic Procedures.}

Methyl (4-nitrobenzoyl)glycinate (3). ${ }^{[15 b]}$ To a suspension of glycine methyl ester hydrochloride (2) (0.677 g, $5.39 \mathrm{mmol})$ and potassium carbonate $(2.23 \mathrm{~g}, 16.17 \mathrm{mmol})$ in acetonitrile (50 mL) cooled to $0{ }^{\circ} \mathrm{C}$, a solution of 4-nitrobenzoil chloride (1) (1.00 g, $\left.5.39 \mathrm{mmol}\right)$ in acetonitrile $(10 \mathrm{~mL})$ was added dropwise. After $15 \mathrm{~h}$ of stirring at $\mathrm{rt}$, the solvent was evaporated under reduced pressure, the residue dissolved in ethyl acetate $(100 \mathrm{~mL})$ and washed with water (2 $\times 20 \mathrm{~mL}$ ) and brine (20 mL). The organic phase was dried over $\mathrm{Na}_{2} \mathrm{SO}_{4}$, filtered and the solvent evaporated under reduced pressure to afford 3 (929 mg) as yellow crystals. Yield 72\% (0.929 g); ${ }^{1} \mathrm{H}$ NMR (400 MHz, [D $\left.\mathrm{D}_{6}\right] \mathrm{DMSO}$ ): $\delta=3.68$ (s, 3H, $\mathrm{CH}_{3}$ ), 4.07 (d, 2H, ${ }^{3} \mathrm{~J}=5.6 \mathrm{~Hz}, \mathrm{CH}_{2}$ ), 8.11 (d, $\left.2 \mathrm{H},{ }^{3} \mathrm{~J}=8.8 \mathrm{~Hz}, \mathrm{Ar}-\mathrm{H}-2,6\right), 8.36$ (d, 2H, $\left.{ }^{3} J=8.8 \mathrm{~Hz}, \mathrm{Ar}-\mathrm{H}-3,5\right), 9.34$ (t, $1 \mathrm{H},{ }^{3} J=5.6 \mathrm{~Hz}, \mathrm{CONH}$ ).

General procedure A. Synthesis of Compounds 4, 17a-b, 17d-e and 27 (with 4 as an Example). Compound 3 (0.920 g, $3.86 \mathrm{mmol}$ ) was dissolved in THF (50 mL), Pd/C (200 mg) was added and the reaction mixture was stirred under hydrogen atmosphere for $3 \mathrm{~h}$. The catalyst was filtered off and the solvent removed under reduced pressure to obtain 4 (0.796 g) as white crystals.

Methyl (4-aminobenzoyl)glycinate (4). White crystals; yield 99\% (0.796 g); mp: $129-131{ }^{\circ} \mathrm{C}$ (130-131 ${ }^{\circ} \mathrm{C}$, lit. ${ }^{[28]}$ ); ${ }^{1} \mathrm{H}$ NMR (400 MHz, [D 6 DMSO): $\delta=3.64$ (s, 3H, $\mathrm{CH}_{3}$ ), 3.93 (d, 2H, ${ }^{3} J=5.6$ Hz, $\mathrm{CH}_{2}$ ), 5.68 (s, 2H, $\mathrm{NH}_{2}$ ), 6.55 (d, 2H, $\left.{ }^{3} \mathrm{~J}=8.4 \mathrm{~Hz}, \mathrm{Ar}-\mathrm{H}-3,5\right), 7.58$ (d, 2H, ${ }^{3} J=8.4 \mathrm{~Hz}, \mathrm{Ar}-\mathrm{H}-$ 2,6), 8.46 (s, $1 \mathrm{H}, \mathrm{CONH}) ;{ }^{13} \mathrm{C} \mathrm{NMR}\left(100 \mathrm{MHz}, \mathrm{CDCl}_{3}\right): \delta=41.87\left(\mathrm{CH}_{2}\right), 52.74\left(\mathrm{CH}_{3}\right), 123.90$, 128.35, 139.15, 149.80, 165.45 (C=O), 170.20 (C=O); IR (ATR): $v=3440,3352,3241,2955$, 2939, 1751, 1635, 1501, 1439, 1411, 1367, 1300, 1205, 1179, 1001, 983, 838, $768 \mathrm{~cm}^{-1}$. 
General procedure B. Synthesis of Compounds 6, 18d-h and 24b-d (with 6 as an Example). To a suspension of 3,4-dichloro-5-methylpyrrole-2-carboxylic acid (280 $\mathrm{mg}, 1.44 \mathrm{mmol}$ ) in anhydrous dichloromethane (16 mL) oxalyl chloride (2 M solution in dichloromethane, $2.20 \mathrm{~mL}$, $4.32 \mathrm{mmol}$ ) was added and the mixture stirred at $\mathrm{rt}$ for $15 \mathrm{~h}$. The solvent was removed under reduced pressure, fresh anhydrous dichloromethane $(4 \mathrm{~mL})$, pyridine $(2 \mathrm{~mL})$ and compound 4 (300 $\mathrm{mg}, 1.44 \mathrm{mmol}$ ) were added and the reaction mixture was stirred at rt for $15 \mathrm{~h}$. The solvent was removed under reduced pressure, the residue dissolved in ethyl acetate $(20 \mathrm{~mL})$ and washed with $1 \mathrm{M} \mathrm{HCl}(2 \times 20 \mathrm{~mL})$ and brine $(2 \times 20 \mathrm{~mL})$. The organic phase was dried over $\mathrm{Na}_{2} \mathrm{SO}_{4}$, filtered and the solvent removed under reduced pressure. To the residue ether (15 mL) was added, the obtained suspension was sonicated, filtered off, washed with ether $(2 \times 5 \mathrm{~mL})$ and dried to afford 6 (245 $\mathrm{mg})$ as a brown solid.

Methyl (4-(3,4-dichloro-5-methyl-1H-pyrrole-2-carboxamido)benzoyl)glycinate (6). Brown solid; yield 42\% (245 mg); mp: > $300{ }^{\circ} \mathrm{C}$; ${ }^{1} \mathrm{H}$ NMR (400 MHz, [D6]DMSO): $\delta=2.25$ (s, 3H, $\mathrm{CH}_{3}$ ), 3.67 (s, 3H, $\mathrm{COOCH}_{3}$ ), 4.01 (d, 2H, ${ }^{3} \mathrm{~J}=6.0 \mathrm{~Hz}, \mathrm{CH}_{2}$ ), 7.77 (d, 2H, $\left.{ }^{3} \mathrm{~J}=8.8 \mathrm{~Hz}, \mathrm{Ar}-\mathrm{H}-2,6\right), 7.88$ (d, $\left.2 \mathrm{H},{ }^{3} \mathrm{~J}=8.8 \mathrm{~Hz}, \mathrm{Ar}-\mathrm{H}-3,5\right), 8.89$ (t, $1 \mathrm{H},{ }^{3} \mathrm{~J}=6.0 \mathrm{~Hz}, \mathrm{NHCH}_{2}$ ), 9.73 (s, 1H, NHAr), 12.29 (s, 1H, Pyrr-NH); ${ }^{13} \mathrm{C}$ NMR (100 MHz, [D $]$ DMSO): $\delta=10.79\left(\mathrm{Pyrr}_{-} \mathrm{CH}_{3}\right), 41.17\left(\mathrm{CH}_{2}\right), 51.71$ $\left(\mathrm{COOCH}_{3}\right)$, 108.62, 111.90, 119.00, 119.29, 128.14, 128.29, 141.53, 157.30, 166.01, 170.48, signal for one C atom not seen; IR (ATR): $v=3386,3245,2953,1735,1640,1593,1522,1504$, 1312, 1216, 1182, $848 \mathrm{~cm}^{-1}$; MS (ESI) m/z = $384.1\left(\mathrm{MH}^{+}\right)$; HRMS for $\mathrm{C}_{16} \mathrm{H}_{16} \mathrm{Cl}_{2} \mathrm{~N}_{3} \mathrm{O}_{4}$ : calculated 384.0518, found 384.0513; HPLC: Agilent Eclipse Plus C18 column (5 $\mu \mathrm{m}, 4.6 \times 150 \mathrm{~mm}$ ); mobile phase: $30-90 \%$ of acetonitrile in TFA (0.1\%) in $16 \mathrm{~min}, 90 \%$ acetonitrile to $20 \mathrm{~min}$; flow rate 1.0 $\mathrm{mL} / \mathrm{min}$; injection volume: $10 \mu \mathrm{L}$; retention time: $9.654 \mathrm{~min}(95.1 \%$ at $280 \mathrm{~nm})$.

General procedure C. Synthesis of Compounds 7, 15a-c, 19e-f and 25c (with 7 as an Example). To a stirred solution of compound 6 (48 mg, $0.12 \mathrm{mmol}$ ) in THF (15 mL) $1 \mathrm{M} \mathrm{NaOH}$ (240 $\mu \mathrm{L}, 0.24 \mathrm{mmol}$ ) was added. The mixture was stirred at rt for $15 \mathrm{~h}$, concentrated under reduced pressure and the residue was acidified with $1 \mathrm{M} \mathrm{HCl}$ to $\mathrm{pH} 1$. The product was extracted with ethyl acetate $(2 \times 20 \mathrm{~mL})$, the combined organic phases washed with water $(2 \times 20 \mathrm{~mL})$ and brine $(20$ $\mathrm{mL}$ ), dried over $\mathrm{Na}_{2} \mathrm{SO}_{4}$, filtered and the solvent evaporated under reduced pressure. To the residue ether ( $5 \mathrm{~mL}$ ) was added, the obtained suspension was sonicated, filtered off, washed with ether (2 $\times 3 \mathrm{~mL}$ ) and dried to give 7 (25 mg) as a brown solid. 
(4-(3,4-Dichloro-5-methyl-1H-pyrrole-2-carboxamido)benzoyl)glycine (7). Brown solid; yield 52\% (25 mg); mp: >250 ${ }^{\circ} \mathrm{C}$; ${ }^{1} \mathrm{H}$ NMR (400 MHz, [D 6 DMSO): $\delta=2.25$ (s, 3H, $\mathrm{CH}_{3}$ ), 3.92 (d, $2 \mathrm{H},{ }^{3} \mathrm{~J}=6.0 \mathrm{~Hz}, \mathrm{CH}_{2}$ ), 7.80 (d, 2H, $\left.{ }^{3} \mathrm{~J}=8.8 \mathrm{~Hz}, \mathrm{Ar}-\mathrm{H}-3,5 / 2,6\right), 7.88$ (d, 2H, ${ }^{3} \mathrm{~J}=8.8 \mathrm{~Hz}, \mathrm{Ar}-\mathrm{H}-$

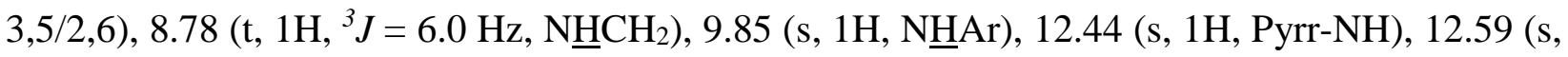
$1 \mathrm{H}, \mathrm{COOH}) ;{ }^{13} \mathrm{C}$ NMR (100 MHz, [D $]$ DMSO): $\delta=10.77\left(\mathrm{CH}_{3}\right), 41.14\left(\mathrm{CH}_{2}\right), 108.75,112.64$, 118.85, 118.96, 128.05, 128.41, 141.64, 157.16, 165.87, 171.42, signal for one C atom not seen; IR (ATR): $v=3355,3246,2979,2935,1728,1647,1595,1524,1142,1317,1215,877,762 \mathrm{~cm}^{-1}$; MS (ESI) m/z = $370.0\left(\mathrm{MH}^{+}\right)$; HRMS for $\mathrm{C}_{15} \mathrm{H}_{14} \mathrm{Cl}_{2} \mathrm{~N}_{3} \mathrm{O}_{4}$ : calculated 370.0361, found 370.0351; HPLC: Agilent Eclipse Plus C18 column (5 $\mu \mathrm{m}, 4.6 \times 150 \mathrm{~mm})$; mobile phase: 30-90\% of acetonitrile in TFA (0.1\%) in $16 \mathrm{~min}, 90 \%$ acetonitrile to $20 \mathrm{~min}$; flow rate $1.0 \mathrm{~mL} / \mathrm{min}$; injection volume: $10 \mu \mathrm{L}$; retention time: $7.995 \mathrm{~min}(98.5 \%$ at $280 \mathrm{~nm})$.

General procedure D. Synthesis of Compounds 8, 9 and 20 (with 8 as an Example). To the solution of compound 5 (96 mg, $0.209 \mathrm{mmol})$ in absolute ethanol (10 mL) hydrazine monohydrate (101 $\mu \mathrm{L}, 2.09 \mathrm{mmol}$ ) was added and the mixture was stirred at reflux for $15 \mathrm{~h}$. The solvent was evaporated under reduced pressure, to the residue absolute ethanol $(10 \mathrm{~mL})$ was added, the obtained precipitate was filtered off and dried to give $8(25 \mathrm{mg})$ as a white solid.

\section{4,5-Dibromo- $N$-(4-((2-hydrazineyl-2-oxoethyl)carbamoyl)phenyl)-1H-pyrrole-2-}

carboxamide (8). White solid; yield 26\% (25 mg); mp: 265-266 ${ }^{\circ} \mathrm{C}$; ${ }^{1} \mathrm{H}$ NMR (400 MHz, [D6]DMSO): $\delta=3.83$ (d, 2H, ${ }^{3} J=6.0 \mathrm{~Hz}, \mathrm{CH}_{2}$ ), 4.26 (s, 2H, NH ), 7.28 (s, 1H, Pyrr-CH), 7.80 (d, $\left.1 \mathrm{H},{ }^{3} \mathrm{~J}=8.8 \mathrm{~Hz}, \mathrm{Ar}-\mathrm{H}-3,5\right), 7.88$ (d, $\left.1 \mathrm{H},{ }^{3} \mathrm{~J}=8.8 \mathrm{~Hz}, \mathrm{Ar}-\mathrm{H}-2,6\right), 8.63$ (t, $\left.1 \mathrm{H},{ }^{3} \mathrm{~J}=6 \mathrm{~Hz}, \mathrm{NHCH}_{2}\right)$, 9.14 (s, 1H, $\underline{H N H}_{2}$ ), 10.05 (s, 1H, NㅌA), 12.97 (s, 1H, Pyrr-NH); ${ }^{13} \mathrm{C}$ NMR (100 MHz, [D6]DMSO): $\delta=56.01\left(\mathrm{CH}_{2}\right), 98.26,106.39,114.17,118.91,127.65,128.17,128.66,141.52$, 157.41, 165.92, 168.43; IR (ATR): $v=3293,3210,3108,1634,1592,1513,1406,1388,1329$, 1289, 1247, 185, 1139, 1063, 998, 970, 931, 883, 829, 805, 754, $649 \mathrm{~cm}^{-1}$; MS (ESI) m/z = 455.9 ([M-H] $]^{-}$); HRMS for $\mathrm{C}_{14} \mathrm{H}_{13} \mathrm{Br}_{2} \mathrm{~N}_{5} \mathrm{O}_{3}$ : calculated 455.9307, found 455.9298; HPLC: Agilent Eclipse Plus C18 column (5 $\mu \mathrm{m}, 4.6 \times 150 \mathrm{~mm}$ ); mobile phase: $30-90 \%$ acetonitrile in TFA (0.1\%) in $16 \mathrm{~min}, 90 \%$ acetonitrile to $20 \mathrm{~min}$; flow rate $1.0 \mathrm{~mL} / \mathrm{min}$; injection volume: $10 \mu \mathrm{L}$; retention time: $4.777 \mathrm{~min}(95.8 \%$ at $280 \mathrm{~nm})$.

General procedure E. Synthesis of Compounds 10 and 21 (with 10 as an Example). The suspension of compound 8 (108 mg, $0.235 \mathrm{mmol}$ ) and 1,1'-carbonyldiimidazole (CDI, $57 \mathrm{mg}, 0.353$ mmol) in 1,4-dioxane (15 mL) was stirred at $101{ }^{\circ} \mathrm{C}$ for $15 \mathrm{~h}$ upon which a clear solution formed. 
The solvent was removed under reduced pressure and the oily residue was purified with flash column chromatography using dichloromethane/methanol (20/1) as an eluent to afford $\mathbf{1 0}$ (25 mg) as a white solid.

4,5-Dibromo- $N$-(4-((5-oxo-4,5-dihydro-1,3,4-oxadiazol-2-yl)methyl)carbamoyl)phenyl)1H-pyrrole-2-carboxamide (10). White solid, yield 22\% (25 mg); mp: $261-263{ }^{\circ} \mathrm{C}$; ${ }^{1} \mathrm{H}$ NMR (400 MHz, [D $\mathrm{D}_{6}$ ]DMSO): $\delta=4.37$ (d, 2H, ${ }^{3} J=5.2 \mathrm{~Hz}, \mathrm{CH}_{2}$ ), 7.28 (s, $1 \mathrm{H}, \mathrm{Pyrr}-\mathrm{CH}$ ), 7.82 (d, $1 \mathrm{H},{ }^{3} J=8.8$ Hz, Ar-H-2,6/3,5), 7.87 (d, $\left.1 \mathrm{H},{ }^{3} J=8.8 \mathrm{~Hz}, \mathrm{Ar}-\mathrm{H}-2,6 / 3,5\right), 8.98$ (t, $1 \mathrm{H},{ }^{3} J=5.6 \mathrm{~Hz}, \mathrm{NHCH}_{2}$ ), 10.07 (s, 1H, N $\underline{H A r}), 12.25$ (s, 1H, NH), 12.97 (s, 1H, NH); ${ }^{13} \mathrm{C}$ NMR (100 MHz, [D6]DMSO): $\delta=35.06$ $\left(\mathrm{CH}_{2}\right), 98.27,106.46,114.23,119.03,127.60,127.95,128.18,141.89,154.48,154.85,157.42$, 165.93; IR (ATR): $v=2231,1761,1639,1593,1544,1519,1410,1388,1322,1246,1224,1186$, 1093, 933, 848, 768, 647 $\mathrm{cm}^{-1}$; MS (ESI) $\mathrm{m} / \mathrm{z}=481.9\left([\mathrm{M}-\mathrm{H}]^{-}\right)$; HRMS for $\mathrm{C}_{15} \mathrm{H}_{11} \mathrm{Br}_{2} \mathrm{~N}_{5} \mathrm{O}_{4}$ : calculated 481.9100, found 481.9110; HPLC: Agilent Eclipse Plus C18 column (5 بm, $4.6 \times 150$ $\mathrm{mm}$ ); mobile phase: $30-90 \%$ acetonitrile in TFA (0.1\%) in $16 \mathrm{~min}, 90 \%$ acetonitrila to $20 \mathrm{~min}$; flow rate $1.0 \mathrm{~mL} / \mathrm{min}$; injection volume: $10 \mu \mathrm{L}$; retention time: $7.578 \mathrm{~min}(98.0 \%$ at $280 \mathrm{~nm})$.

General procedure F. Synthesis of Compounds 13 and 23a-b (with 13 as an Example). To the solution of 3-hydroxy-4-nitrobenzoic acid (12) (10.00 g, $55 \mathrm{mmol})$ in methanol (500 mL) cooled on ice bath thionyl chloride (32.20 mL, $165 \mathrm{mmol}$ ) was added dropwise. The mixture was stirred at rt for $15 \mathrm{~h}$. The solvent was evaporated under reduced pressure to obtain 13 (10.35 g) as a yellow solid.

Methyl 3-hydroxy-4-nitrobenzoate (13). Yellow solid, yield 97\% (10.53 g); mp: 87-91 C (86$88^{\circ} \mathrm{C}$, lit. ${ }^{[29]}$ ); ${ }^{1} \mathrm{H}$ NMR (400 MHz, [D $\left.\mathrm{D}_{6}\right] \mathrm{DMSO}$ ): $\delta=3.88$ (s, 3H, $\mathrm{COOCH}_{3}$ ), 7.49 (dd, $1 \mathrm{H},{ }^{3} \mathrm{~J}=$ $\left.8.4 \mathrm{~Hz},{ }^{4} J=1.6 \mathrm{~Hz}, \mathrm{Ar}-\mathrm{H}-6\right), 7.69$ (d, 1H, $\left.{ }^{4} J=1.6 \mathrm{~Hz}, \mathrm{Ar}-\mathrm{H}-2\right), 7.96$ (d, $1 \mathrm{H},{ }^{3} J=8.4 \mathrm{~Hz}, \mathrm{Ar}-\mathrm{H}-5$ ), 11.52 (s, $1 \mathrm{H}, \mathrm{OH}) ;{ }^{13} \mathrm{C}$ NMR (100 MHz, [D $]$ DMSO): $\delta=52.73\left(\mathrm{CH}_{3}\right), 119.33,119.39,125.51$, 134.44, 140.15, 151.26, 164.72 (C=O); IR (ATR): $v=3305$, 3053, 2960, 1720, 1622, 1586, 1521, 1476, 1434, 1323, 1283, 1220, 1147, 1097, 1066, 966, 891, 842, 797, 780, 743, $666 \mathrm{~cm}^{-1}$.

Methyl 3-methoxy-4-nitrobenzoate (14a). ${ }^{[30]}$ To a stirred suspension of compound 13 (3.43 g, $17.4 \mathrm{mmol}$ ) and potassium carbonate (3.61 g, $26.1 \mathrm{mmol}$ ) in $N, N$-dimethylformamide (30 mL) methyl iodide (2.20 mL, $34.8 \mathrm{mmol}$ ) was added dropwise. The mixture was stirred at rt for $15 \mathrm{~h}$, concentrated under reduced pressure, the residue was dissolved in ethyl acetate $(20 \mathrm{~mL})$ and the organic phase was washed with water $(2 \times 30 \mathrm{~mL})$ and brine $(30 \mathrm{~mL})$. The organic phase was dried over $\mathrm{Na}_{2} \mathrm{SO}_{4}$, filtered and the solvent removed under reduced pressure to obtain 14a (3.01 g) as a 
pale yellow solid. Yield 82\% (3.01 g); mp: 90-93 ${ }^{\circ} \mathrm{C} ;{ }^{1} \mathrm{H}$ NMR (400 MHz, [D 6 DMSO): $\delta=3.92$ (s, 3H, $\mathrm{OCH}_{3}$ ), 4.01 (s, 3H, $\mathrm{COOCH}_{3}$ ), 7.68 (dd, $\left.1 \mathrm{H},{ }^{3} \mathrm{~J}=8.4 \mathrm{~Hz},{ }^{4} \mathrm{~J}=1.2 \mathrm{~Hz}, \mathrm{Ar}-\mathrm{H}-6\right), 7.78$ (d, $\left.1 \mathrm{H},{ }^{4} \mathrm{~J}=1.2 \mathrm{~Hz}, \mathrm{Ar}-\mathrm{H}-2\right), 8.00$ (d, $\left.1 \mathrm{H},{ }^{3} \mathrm{~J}=8.4 \mathrm{~Hz}, \mathrm{Ar}-\mathrm{H}-5\right) ;{ }^{13} \mathrm{C}$ NMR (100 MHz, [D $]$ DMSO): $\delta$ $=52.84\left(\mathrm{COOCH}_{3}\right), 56.86\left(\mathrm{OCLH}_{3}\right), 114.43,121.22,125.10,134.27,142.13,151.48,164.72$ $\left(\mathrm{COOCH}_{3}\right)$; IR (ATR): $v=2959,1726,1610,1587,1523,1487,1435,1408,1348,1290,1241$, 1186, 1147, 1114, 1083, 1019, 983, 914, 887, 837, 788, 772, 742, 685, $616 \mathrm{~cm}^{-1}$; MS (ESI) m/z = 212.1 $\left(\mathrm{MH}^{+}\right)$; HRMS for $\mathrm{C}_{9} \mathrm{H}_{10} \mathrm{NO}_{5}$ : calculated 212.0559, found 212.0554.

3-Methoxy-4-nitrobenzoic acid (15a). Synthesized according to General procedure C with methanol (50 mL) as solvent. Pale yellow solid; yield $86 \%$ (2.38 g); mp: $229-233{ }^{\circ} \mathrm{C}\left(230-233{ }^{\circ} \mathrm{C}\right.$, lit. ${ }^{[31]}$ ); ${ }^{1} \mathrm{H}$ NMR (400 MHz, [D $]$ DMSO): $\delta=3.99$ (s, 3H, $\left.\mathrm{OCH}_{3}\right), 7.66\left(\mathrm{dd}, 1 \mathrm{H},{ }^{3} \mathrm{~J}=8.4 \mathrm{~Hz},{ }^{4} \mathrm{~J}=\right.$ 1.2 Hz, Ar-H-6), 7.77 (d, 1H, $\left.{ }^{4} \mathrm{~J}=1.2 \mathrm{~Hz}, \mathrm{Ar}-\mathrm{H}-2\right), 7.98$ (d, $1 \mathrm{H},{ }^{3} \mathrm{~J}=8.4 \mathrm{~Hz}, \mathrm{Ar}-\mathrm{H}-5$ ), 13.68 (s, $1 \mathrm{H}, \mathrm{COOH}) ;{ }^{13} \mathrm{C}$ NMR (100 MHz, [D $]$ DMSO): $\delta=56.75\left(\mathrm{OCH}_{3}\right), 114.50,121.27,124.97,135.67$, 141.88, 151.46, 165.76 (ㄷOH); IR (ATR): $v=3398,2875,2538,1753,1717,1688,1606,1588$, 1524, 1494, 1455, 1411, 1356, 1300, 1254, 1230, 1184, 1122, 1088, 1013, 922, 880, 836, 745, 694, $616 \mathrm{~cm}^{-1}$.

General procedure G. Synthesis of Compounds 16a-f (with 16a as an Example). To a solution of compound 15a (2.32 g, $11.8 \mathrm{mmol})$ and TBTU (4.90 g, $15.3 \mathrm{mmol})$ in dichloromethane (80 mL) $\mathrm{N}$-methylmorpholine (3.9 mL, $35.2 \mathrm{mmol}$ ) was added and the mixture was stirred at rt for 15 min. Glycine methyl ester hydrochloride (2) (1.62 g, $12.9 \mathrm{mmol}$ ) was added and the mixture was stirred at rt for $2 \mathrm{~h}$. The solvent was removed under reduced pressure, the residue was dissolved in ethyl acetate $(20 \mathrm{~mL})$ and the organic phase was washed with water $(2 \times 20 \mathrm{~mL})$, saturated aqueous $\mathrm{NaHCO}_{3}$ solution $(2 \times 20 \mathrm{~mL}), 1 \mathrm{M} \mathrm{HCl}(2 \times 20 \mathrm{~mL})$ and brine $(2 \times 20 \mathrm{~mL})$. The organic phase was dried over $\mathrm{Na}_{2} \mathrm{SO}_{4}$, filtered and the solvent removed under reduced pressure to afford 16a (2.27 $\mathrm{g})$ as a yellow solid.

Methyl (3-methoxy-4-nitrobenzoyl)glycinate (16a). Yellow solid; yield 72\% (2.27 g); mp: 102-105 ${ }^{\circ} \mathrm{C}$; ${ }^{1} \mathrm{H}$ NMR (400 MHz, [D $]$ DMSO): $\delta=3.68$ (s, 3H, $\mathrm{OCH}_{3}$ ), 3.99 (s, 3H, $\mathrm{OCH}_{3}$ ), 4.07 (d, $2 \mathrm{H},{ }^{3} \mathrm{~J}=5.5 \mathrm{~Hz}, \mathrm{CH}_{2}$ ), 7.59 (dd, $\left.1 \mathrm{H},{ }^{3} \mathrm{~J}=8.4 \mathrm{~Hz},{ }^{4} \mathrm{~J}=1.6 \mathrm{~Hz}, \mathrm{Ar}-\mathrm{H}-6\right), 7.77$ (d, $1 \mathrm{H},{ }^{4} \mathrm{~J}=1.6$ $\mathrm{Hz}, \mathrm{Ar}-\mathrm{H}-2), 8.00$ (d, $\left.1 \mathrm{H},{ }^{3} \mathrm{~J}=8.4 \mathrm{~Hz}, \mathrm{Ar}-\mathrm{H}-5\right), 9.28$ (t, $\left.1 \mathrm{H},{ }^{3} \mathrm{~J}=5.5 \mathrm{~Hz}, \mathrm{NH}\right) ;{ }^{13} \mathrm{C} \mathrm{NMR}(100 \mathrm{MHz}$, [D $]$ DMSO): $\delta=41.31\left(\mathrm{CH}_{2}\right), 51.83\left(\mathrm{COOCH}_{3}\right), 56.80\left(\mathrm{OCH}_{3}\right), 113.01,119.32,125.04,138.43$, 140.90, 151.62, 164.87 (CONH), $170.08\left(\mathrm{COOCH}_{3}\right)$; IR (ATR): $v=3346,3075,2965,1738,1643$, 1608, 1589, 1549, 1519, 1493, 1458, 1433, 1408, 1364, 1328, 1304, 1255, 1210, 1146, 1100, 1069, 
1025, 1004, 966, 896, 837, 787, 772, 744, 705, 685, $639 \mathrm{~cm}^{-1}$; MS (ESI) m/z = $267.1\left([\mathrm{M}-\mathrm{H}]^{-}\right)$; HRMS for $\mathrm{C}_{11} \mathrm{H}_{11} \mathrm{~N}_{2} \mathrm{O}_{6}$ : calculated 267.0617, found 267.0611.

Methyl (4-amino-3-methoxybenzoyl)glycinate (17a). Synthesized according to General procedure A with methanol (20 mL) as solvent. Brown oil; yield 99\% (1.845 g); ${ }^{1} \mathrm{H}$ NMR (400 MHz, [D $\mathrm{D}_{6}$ ]DMSO): $\delta=3.65$ (s, 3H, $\mathrm{OCH}_{3}$ ), 3.81 (s, 3H, $\left.\mathrm{OCH}_{3}\right), 3.96\left(\mathrm{~d}, 2 \mathrm{H},{ }^{3} J=5.6 \mathrm{~Hz}, \mathrm{CH}_{2}\right.$ ), 5.33 (s, 2H, NH${ }_{2}$ ), 6.62 (d, $\left.1 \mathrm{H},{ }^{3} J=8.4 \mathrm{~Hz}, \mathrm{Ar}-\mathrm{H}-5\right), 7.30$ (dd, $1 \mathrm{H},{ }^{3} J=8.4 \mathrm{~Hz},{ }^{4} J=1.2 \mathrm{~Hz}, \mathrm{Ar}-\mathrm{H}-$ 6), $7.33\left(\mathrm{~d}, 1 \mathrm{H},{ }^{4} \mathrm{~J}=1.2 \mathrm{~Hz}, \mathrm{Ar}-\mathrm{H}-2\right), 8.56\left(\mathrm{t}, 1 \mathrm{H},{ }^{3} \mathrm{~J}=5.6 \mathrm{~Hz}, \mathrm{NH}\right) ;{ }^{13} \mathrm{C}$ NMR $(100 \mathrm{MHz}$, [D $]$ DMSO): $\delta=41.63\left(\mathrm{CH}_{2}\right), 52.09\left(\mathrm{COO}^{2} \mathrm{H}_{3}\right), 55.77\left(\mathrm{OCH}_{3}\right), 109.93,112.51,121.10,121.71$, 141.78, 145.70, 167.05 (CONH), 171.31 ( $\left.\mathrm{COOCH}_{3}\right)$; IR (ATR): $v=3343,2953,1739,1614,1574$, 1543, 1503, 1463, 1438, 1406, 1367, 1301, 1207, 1181, 1146, 1075, 1032, 1012, 978, 873, 828, $761 \mathrm{~cm}^{-1}$; MS (ESI) $\mathrm{m} / \mathrm{z}=239.1\left(\mathrm{MH}^{+}\right)$; HRMS for $\mathrm{C}_{11} \mathrm{H}_{15} \mathrm{~N}_{2} \mathrm{O}_{4}$ : calculated 239.1032, found 239.1038 .

General procedure H. Synthesis of Compounds 17c and 17f (with 17c as an Example). A mixture of compound 16c (143 mg, $0.42 \mathrm{mmol}$ ) and $\mathrm{SnCl}_{2}$ (394 mg, $2.08 \mathrm{mmol}$ ) in ethyl acetate $(2 \mathrm{~mL})$ and ethanol $(2 \mathrm{~mL})$ was stirred at $55{ }^{\circ} \mathrm{C}$ for $24 \mathrm{~h}$. The mixture was poured slowly into an aqueous $\mathrm{NaHCO}_{3}$ solution $(20 \mathrm{~mL}$ ) and stirred vigoroursly for $2 \mathrm{~h}$, then extracted with EtOAc (20 $\mathrm{mL}$ ) and washed with brine (20 mL). The organic layer was dried over $\mathrm{Na}_{2} \mathrm{SO}_{4}$, filtered and the solvent was evaporated under reduced pressure. The residue was purified with flash column chromatography using dichloromethane/methanol $(30 / 1 \rightarrow 20 / 1)$ as an eluent to give compound 17c (58 mg) as a brown oil.

Methyl (4-amino-3-(benzyloxy)benzoyl)glycinate (17c). Brown oil; yield 44\% (58 mg); ${ }^{1} \mathrm{H}$ NMR (400 MHz, [D $\mathrm{D}_{6}$ ]DMSO): $\delta=3.65$ (s, 3H, $\mathrm{COOCH}_{3}$ ), 3.96 (d, $2 \mathrm{H},{ }^{3} J=5.6 \mathrm{~Hz}, \mathrm{NHC}_{2}$ ), 5.15 (s, $2 \mathrm{H}, \mathrm{OC} \underline{\mathrm{H}}_{2} \mathrm{Ar}$ ), 5.37 (s, 2H, NH${ }_{2}$ ), 6.66-7.53 (m, 8H, $\left.8 \times \mathrm{Ar}-\mathrm{H}\right), 8.55$ (t, $\left.1 \mathrm{H},{ }^{3} \mathrm{~J}=5.6 \mathrm{~Hz}, \mathrm{NH}\right)$; ${ }^{13} \mathrm{C}$ NMR (100 MHz, [D $\left.\left.\mathrm{D}_{6}\right] \mathrm{DMSO}\right): \delta=41.14\left(\mathrm{CH}_{2} \mathrm{COOCH}_{3}\right), 51.61\left(\mathrm{COOCH}_{3}\right), 69.33\left(\mathrm{OCH}_{2} \mathrm{Ar}\right)$, 111.07, 112.37, 120.62, 121.45, 127.38, 127.70, 128.37, 137.19, 141.59, 144.16, 166.46 (ArCONH), 170.80 ( COOCH $\left._{3}\right)$; IR (ATR): $v=3344,2951,1742,1614,1574,1543,1503,1454,1435$, 1405, 1367, 1301, 1205, 1144, 1076, 1009, 925, 827, 759, $697 \mathrm{~cm}^{-1}$; MS (ESI) m/z = $315.1\left(\mathrm{MH}^{+}\right)$; HRMS for $\mathrm{C}_{17} \mathrm{H}_{19} \mathrm{~N}_{2} \mathrm{O}_{4}$ : calculated 315.1345, found 315.1338.

General procedure I. Synthesis of Compounds 18a-c (with 18a as an Example). To a suspension of 4,5-dibromopyrrole-2-carboxylic acid (296 mg, $1.10 \mathrm{mmol}$ ) and TBTU (405 mg, $1.26 \mathrm{mmol}$ ) in dichloromethane $(10 \mathrm{~mL}) \mathrm{N}$-methylmorpholine (350 $\mu \mathrm{L}, 3.15 \mathrm{mmol})$ was added and 
the suspension was stirred at rt for 30 min upon which a clear solution formed. Compound 17a (145 mg, $1.05 \mathrm{mmol}$ ) and DMAP (14 mg, $0.115 \mathrm{mmol}$ ) were added and the mixture was stirred at $60{ }^{\circ} \mathrm{C}$ for $15 \mathrm{~h}$. The solvent was removed under reduced pressue, to the residue ethyl acetate (10 $\mathrm{ml})$ and water $(10 \mathrm{~mL})$ were added and the organic phase was washed with aqueous $\mathrm{NaHCO}_{3}$ solution $(10 \mathrm{~mL}), 1 \mathrm{M} \mathrm{HCl}(10 \mathrm{~mL})$ and brine $(2 \times 10 \mathrm{~mL})$, dried over $\mathrm{Na}_{2} \mathrm{SO}_{4}$, filtered and the solvent removed under reduced pressure. The crude product was purified with flash column chromatography using ethyl acetate/petroleum ether (1/1) as an eluent to obtain a white solid which was further purified by sonicating with ether $(25 \mathrm{~mL})$, filtering off the precipitate and drying to give 18a (40 mg) as a white solid.

Methyl (4-(4,5-dibromo-1H-pyrrole-2-carboxamido)-3-methoxybenzoyl)glycinate (18a). White solid; yield 10\% (40 mg); mp: 230-233 ${ }^{\circ} \mathrm{C}$; ${ }^{1} \mathrm{H}$ NMR (400 MHz, [D6]DMSO): $\delta=3.67$ (s, $3 \mathrm{H}, \mathrm{OCH}_{3}$ ), 3.92 (s, 3H, $\mathrm{OCH}_{3}$ ), 4.04 (d, 2H, ${ }^{3} \mathrm{~J}=6.0 \mathrm{~Hz}, \mathrm{CONHC}_{2}$ ), 7.27 (d, $1 \mathrm{H},{ }^{4} \mathrm{~J}=2.8 \mathrm{~Hz}$, Pyrr-CH), 7.52 (dd, 1H, ${ }^{3} J=8.4$ Hz, ${ }^{4} J=1.6 \mathrm{~Hz}$, Ar-H-6), 7.57 (d, 1H, ${ }^{4} J=1.6 \mathrm{~Hz}$, Ar-H-2), 7.92

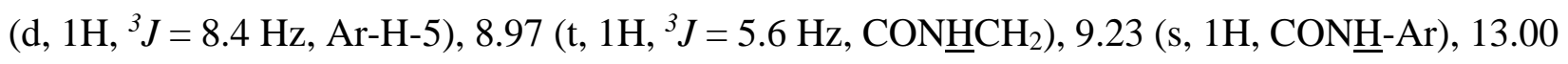
(s, 1H, Pyrr-NH); ${ }^{13} \mathrm{C}$ NMR (100 MHz, [D $]$ DMSO): $\delta=41.24\left(\mathrm{CH}_{2}\right), 51.74\left(\mathrm{COOCH}_{3}\right), 55.89$ $\left(\mathrm{OCL}_{3}\right), 98.40,106.19,110.07,114.28,119.63,122.65,127.53,129.45,130.03,150.23,157.12$, 166.00 (ㅇNH), $170.45\left(\underline{\mathrm{COOCH}}_{3}\right)$; IR (ATR): $v=3409,3368,3229,3110,2957,1752,1717$, 1650, 1600, 1547, 1523, 1487, 1433, 1411, 1391, 1374, 1350, 1310, 1270, 1251, 1214, 1178, 1134, 1075, 1032, 1009, 973, 873, 806, 783, 755, 710, 652, $618 \mathrm{~cm}^{-1}$; MS (ESI) m/z = $485.9\left([\mathrm{M}-\mathrm{H}]^{-}\right)$; HRMS for $\mathrm{C}_{16} \mathrm{H}_{14} \mathrm{~N}_{3} \mathrm{O}_{5} \mathrm{Br}_{2}$ : calculated 485.9300, found 485.9308; HPLC: Agilent Eclipse Plus C18 column ( $5 \mu \mathrm{m}, 4.6 \times 150 \mathrm{~mm})$; mobile phase: $30-90 \%$ of acetonitrile in TFA $(0.1 \%)$ in $16 \mathrm{~min}$, $90 \%$ acetonitrile to $20 \mathrm{~min}$; flow rate $1.0 \mathrm{~mL} / \mathrm{min}$; injection volume: $10 \mu \mathrm{L}$; retention time: 9.881 $\min (99.0 \%$ at $280 \mathrm{~nm})$.

General procedure J. Synthesis of Compounds 19a-d and 19g (with 19a as an Example). To a stirred solution of compound 18a (34 mg, $0.070 \mathrm{mmol}$ ) in methanol (10 mL) $2 \mathrm{M} \mathrm{NaOH} \mathrm{(110}$ $\mu \mathrm{L}, 0.210 \mathrm{mmol}$ ) was added. The mixture was stirred at rt for $15 \mathrm{~h}$, concentrated under reduced

pressure and the residue was acidified with $1 \mathrm{M} \mathrm{HCl}$ to $\mathrm{pH} 1$. The product was extracted with ethyl acetate $(2 \times 10 \mathrm{~mL})$, the combined organic phases washed with water $(2 \times 10 \mathrm{~mL})$ and brine $(10$ $\mathrm{mL}$ ), dried over $\mathrm{Na}_{2} \mathrm{SO}_{4}$, filtered and the solvent evaporated under reduced pressure to afford 19a (18 mg) as a white solid. 
(4-(4,5-Dibromo-1H-pyrrole-2-carboxamido)-3-methoxybenzoyl)glycine (19a). White solid; yield 94\% (18 mg); mp: 272-275 ${ }^{\circ} \mathrm{C} ;{ }^{1} \mathrm{H}$ NMR (400 MHz, [D 6 DMSO): $\delta=3.92-3.95$ (m, 5H, $\mathrm{CH}_{2}$, $\mathrm{CH}_{3}$ ), 7.26 (d, $1 \mathrm{H},{ }^{4} \mathrm{~J}=2.4 \mathrm{~Hz}$, Pyrr-CH), 7.51-7.57 (m, 2H, Ar-H-2,5), 7.91 (d, 1H, ${ }^{3} J=8.0 \mathrm{~Hz}$,

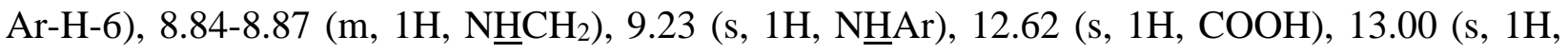
Pyrr-NH); ${ }^{13} \mathrm{C}$ NMR (100 MHz, [D 6 DMSO): $\delta=41.21$ ( $\left.\underline{\mathrm{CH}}_{2}\right), 55.88\left(\mathrm{OC}_{3}\right), 98.40,106.17$, 110.05, 114.26, 119.59, 122.65, 127.55, 129.33, 130.30, 150.22, 157.12, 165.88 (Ar-CONH), 171.39 (COOH); IR (ATR): $v=3401,3209,2841,2528,1719,1702,1663,1620,1665,1594$, 1544, 1519, 1489, 1432, 1409, 1392, 1349, 1321, 1284, 1257, 1217, 1181, 1133, 1076, 1034, 1010, 972, 897, 873, 802, 757, 684, $617 \mathrm{~cm}^{-1}$; MS (ESI) m/z = $471.9\left([\mathrm{M}-\mathrm{H}]^{-}\right)$; HRMS for $\mathrm{C}_{15} \mathrm{H}_{12} \mathrm{~N}_{3} \mathrm{O}_{5} \mathrm{Br}_{2}$ : calculated 471.9144, found 471.9134; HPLC: Agilent Eclipse Plus C18 column (5 $\mu \mathrm{m}, 4.6 \times 150 \mathrm{~mm}$ ); mobile phase: $30-90 \%$ of acetonitrile in TFA (0.1\%) in 16 min, $90 \%$ acetonitrile to $20 \mathrm{~min}$; flow rate $1.0 \mathrm{~mL} / \mathrm{min}$; injection volume: $10 \mu \mathrm{L}$; retention time: $8.191 \mathrm{~min}$ $(95.9 \%$ at $280 \mathrm{~nm})$.

\section{4,5-Dibromo- $N$-(4-((2-hydrazineyl-2-oxoethyl)carbamoyl)-2-isopropoxyphenyl)-1H-}

pyrrole-2-carboxamide (20). Synthesized according to General procedure D with the addition of further 10 eq. of hydrazine monohydrate after $15 \mathrm{~h}(34 \mu \mathrm{L}, 0.700 \mathrm{mmol})$ and stirring at reflux for additional $48 \mathrm{~h}$. The product was isolated without evaporating the solvent but with filtering off the white precipitate (20, $34 \mathrm{mg}$ ) formed during reaction. White solid; yield 92\% (34 mg); mp: 253$257{ }^{\circ} \mathrm{C} ;{ }^{1} \mathrm{H}$ NMR (400 MHz, [D 6 DMSO): $\delta=1.35$ (d, 6H, $\left.{ }^{3} J=5.6 \mathrm{~Hz}, \mathrm{CH}\left(\mathrm{CH}_{3}\right)_{2}\right), 3.85$ (d, 2H, ${ }^{3} J=5.6 \mathrm{~Hz}, \mathrm{CH}_{2}$ ), 4.29 (s, 2H, $\mathrm{NH}_{2}$ ), 4.71 (spt, $\left.1 \mathrm{H},{ }^{3} J=5.6 \mathrm{~Hz}, \mathrm{C} \underline{\mathrm{H}}\left(\mathrm{CH}_{3}\right)_{2}\right), 7.17$ (s, $1 \mathrm{H}$, Pyrr-CH), 7.50-7.58 (m, 2H, Ar-H-2,6), 7.92 (d, 1H, $\left.{ }^{3} \mathrm{~J}=8.8 \mathrm{~Hz}, \mathrm{Ar}-\mathrm{H}-5\right), 8.72$ (s, 1H, $\underline{H C H}_{2}$ ), 9.04 (s, 1H,

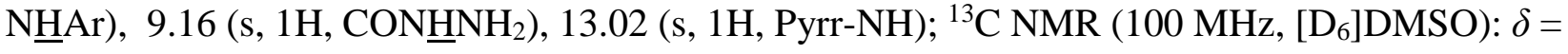
$21.76\left(\mathrm{CH}\left(\underline{\mathrm{CH}}_{3}\right)_{2}\right), 41.39\left(\mathrm{CH}_{2}\right), 71.31\left(\underline{\mathrm{CH}}\left(\mathrm{CH}_{3}\right)_{2}\right), 98.44,106.31,112.91,113.81,119.87,122.47$,

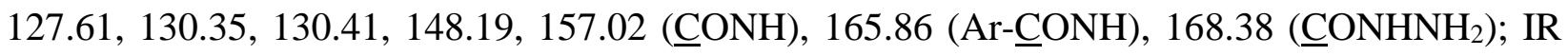
(ATR): $v=3419,3316,3204,2969,1660,1619,1599,1510,1483,1441,1418,1389,1354,1302$, 1272, 1228, 1203, 1177, 1127, 968, 882, 809, 752, 695, 652, $613 \mathrm{~cm}^{-1}$; MS (ESI) m/z = 514.0 ([M$\mathrm{H}]^{-}$); HRMS for $\mathrm{C}_{17} \mathrm{H}_{18} \mathrm{~N}_{5} \mathrm{O}_{4} \mathrm{Br}_{2}$ : calculated 513.9726, found 513.9727; HPLC: Agilent Eclipse Plus C18 column (5 $\mu \mathrm{m}, 4.6 \times 150 \mathrm{~mm})$; mobile phase: $30-90 \%$ of acetonitrile in TFA $(0.1 \%)$ in $16 \mathrm{~min}, 90 \%$ acetonitrile to $20 \mathrm{~min}$; flow rate $1.0 \mathrm{~mL} / \mathrm{min}$; injection volume: $10 \mu \mathrm{L}$; retention time: $7.641 \mathrm{~min}(97.1 \%$ at $280 \mathrm{~nm})$. 


\section{4,5-Dibromo- $N$-(2-isopropoxy-4-(((5-oxo-4,5-dihydro-1,3,4-oxadiazol-2-}

yl)methyl)carbamoyl)phenyl)-1H-pyrrole-2-carboxamide (21). Synthesized according to General procedure E and additionally purifying the crude product by adding ether (10 $\mathrm{mL})$ to the crude product, sonicating the obtained suspension, filtering off the solid, washing with ether $(2 \times$ $5 \mathrm{~mL}$ ) and drying to give 21 (12 mg) as a white solid. Yield 39\% (12 mg); mp: 160-162 ${ }^{\circ} \mathrm{C} ;{ }^{1} \mathrm{H}$ NMR (400 MHz, [D $\left.\left.\mathrm{D}_{6}\right] \mathrm{DMSO}\right): \delta=1.35$ (d, 6H, $\left.{ }^{3} \mathrm{~J}=5.6 \mathrm{~Hz}, \mathrm{CH}\left(\mathrm{CH}_{3}\right)_{2}\right), 4.40$ (d, 2H, ${ }^{3} \mathrm{~J}=5.6 \mathrm{~Hz}$, $\mathrm{NHCH}_{2}$ ), 4.70 (spt, $\left.1 \mathrm{H},{ }^{3} \mathrm{~J}=5.6 \mathrm{~Hz}, \mathrm{C} \underline{\mathrm{H}}\left(\mathrm{CH}_{3}\right)_{2}\right), 7.13$ (s, 1H, Pyrr-CH), 7.50-7.57 (m, 2H, Ar-H2,6), 7.99 (d, 1H, Ar-H-5), 9.04 (t, 1H, ${ }^{3} J=5.6$ Hz, $\underline{H C H}_{2}$ ), 9.10 (s, 1H, N $\underline{H A r}$ ), 12.35 (m, 2H, Pyrr-NH, NH); MS (ESI) m/z = $540.0\left([\mathrm{M}-\mathrm{H}]^{-}\right)$; HRMS for $\mathrm{C}_{18} \mathrm{H}_{16} \mathrm{Br}_{2} \mathrm{~N}_{5} \mathrm{O}_{5}$ : calculated 539.9518, found 539.9518; HPLC: Agilent Eclipse Plus C18 column (5 $\mu \mathrm{m}, 4.6 \times 150 \mathrm{~mm})$; mobile phase: 30-90\% of acetonitrile in TFA (0.1\%) in $16 \mathrm{~min}$, 90\% acetonitrile to $20 \mathrm{~min}$; flow rate $1.0 \mathrm{~mL} / \mathrm{min}$; injection volume: $10 \mu \mathrm{L}$; retention time: $10.671 \mathrm{~min}(95.1 \%$ at $280 \mathrm{~nm})$.

Methyl 4-aminobenzoate (23a). Synthesized according to General procedure $F$ with heaing the reaction mixture at $70{ }^{\circ} \mathrm{C}$. After the completion of the reaction, the solvent was evaporated under reduced pressure, the residue was dissolved in ethyl acetate $(120 \mathrm{~mL})$ and washed with aqueous $\mathrm{NaHCO}_{3}$ solution $(3 \times 40 \mathrm{~mL})$ and brine $(3 \times 40 \mathrm{~mL})$. The organic phase was dried over $\mathrm{Na}_{2} \mathrm{SO}_{4}$, filtered and the solvent removed under reduced pressure to obtain 23a (4.88g) as off-white crystals. Yield 89\% (4.88 g); mp: 106-107 ${ }^{\circ} \mathrm{C}$ (107-110 ${ }^{\circ} \mathrm{C}$, lit); ${ }^{1} \mathrm{H}$ NMR (400 MHz, [D6]DMSO): $\delta=3.88$ (s, 3H, $\mathrm{CH}_{3}$ ), 4.08 (s, 2H, NH ), 6.66 (d, 2H, $\left.{ }^{3} \mathrm{~J}=8.8 \mathrm{~Hz}, \mathrm{Ar}-\mathrm{H}-3,5\right), 7.87$ (d, 2H, ${ }^{3} \mathrm{~J}=8.8 \mathrm{~Hz}, \mathrm{Ar}-$ H-2,6); IR (ATR): $v=3464,3368,3248,2952,1677,1592,1520,1434,1313,1248,1166,1075$, $964,835,769,698 \mathrm{~cm}^{-1}$.

Methyl 4-(4,5-dibromo-1H-pyrrole-2-carboxamido)benzoate (24a). To a suspension of 4,5dibromopyrrole-2-carboxylic acid (268 mg, $0.997 \mathrm{mmol}$ ) in anhydrous dichloromethane $(9 \mathrm{~mL})$ oxalyl chloride (392 $\mu \mathrm{L}, 4.48 \mathrm{mmol}$ ) was added and the mixture stirred at $\mathrm{rt}$ for $15 \mathrm{~h}$. The solvent was removed under reduced pressure, fresh anhydrous dichloromethane $(9 \mathrm{~mL})$, pyridine $(4.5 \mathrm{~mL})$ and compound 23a (126 mg, $0.833 \mathrm{mmol}$ ) were added and the reaction mixture stirred at rt for 15 h. The solvent was removed under reduced pressure, to the residue ethyl acetate (15 mL) and water (10 mL) were added. The undissolved solid was filtered off, phases were separated and the organic phase was washed with aqueous $\mathrm{NaHCO}_{3}$ solution $(3 \times 10 \mathrm{~mL})$ and brine $(2 \times 10 \mathrm{~mL})$, dried over $\mathrm{Na}_{2} \mathrm{SO}_{4}$, filtered and the solvent removed under reduced pressure. To the crude product methanol (10 mL) was added, the obtained suspension was sonicated, heated, filtered off, washed with 
methanol (2 $\times 5 \mathrm{~mL})$ and dried to give 24a (96 mg) as a pale brown solid. Yield 29\% (96 mg); mp: 230-233 ${ }^{\circ} \mathrm{C}$; ${ }^{1} \mathrm{H}$ NMR (400 MHz, [D 6 ]DMSO): $\delta=3.84$ (s, 3H, $\mathrm{CH}_{3}$ ), 7.30 (d, $1 \mathrm{H},{ }^{4} J=2.4 \mathrm{~Hz}$, Pyrr-CH), 7.88 (d, 2H, ${ }^{3} J=8.8 \mathrm{~Hz}$, Ar-H-2,6), 7.96 (d, 2H, ${ }^{3} J=8.8 \mathrm{~Hz}$, Ar-H-3,5), 10.14 (s, 1H, CONH), 13.01 (d, $1 \mathrm{H},{ }^{4} J=2.0 \mathrm{~Hz}$, Pyrr-NH); ${ }^{13} \mathrm{C}$ NMR (100 MHz, [D 6 DMSO): $\delta=51.89\left(\mathrm{CH}_{3}\right)$, 98.30, 106.68, 114.43, 119.10, 123.97, 127.50, 130.19, 143.36, 157.48, 165.80; IR (ATR): $v=$ 3395, 3240, 3113, 2949, 1697, 1591, 1516, 1409, 1273, 1219, 1174, 1106, 974, 857, 816, $750 \mathrm{~cm}^{-}$ 1; MS (ESI) $\mathrm{m} / \mathrm{z}=398.9\left([\mathrm{M}-\mathrm{H}]^{-}\right)$; HRMS for $\mathrm{C}_{13} \mathrm{H}_{9} \mathrm{Br}_{2} \mathrm{~N}_{2} \mathrm{O}_{3}$ : calculated 398.8980, found 398.8985; HPLC: Agilent Eclipse Plus C18 column (4.6 mm × $150 \mathrm{~mm}$ ); mobile phase: 30-90\% acetonitrile in TFA (0.1\%) in $16 \mathrm{~min}, 90 \%$ acetonitrile to $20 \mathrm{~min}$; flow rate $1 \mathrm{~mL} / \mathrm{min}$; injection volume $10 \mu \mathrm{L}$; retention time: $11.022(96.4 \%$ at $280 \mathrm{~nm})$.

General procedure K. Synthesis of Compounds 25a-b and 29 (with 25a as an example). To a stirred solution of compound 24a (70 mg, $0.174 \mathrm{mmol}$ ) in a mixture of methanol and THF (3.5:1, $9 \mathrm{~mL}) 1 \mathrm{M} \mathrm{NaOH}(696 \mu \mathrm{L}, 0.696 \mathrm{mmol}$ ) was added. The mixture was stirred at rt for $15 \mathrm{~h}$. Additional 4 eq. of $1 \mathrm{M} \mathrm{NaOH}(696 \mu \mathrm{L}, 0.696 \mathrm{mmol})$ were added and the mixture was stirred at $60{ }^{\circ} \mathrm{C}$ for $5 \mathrm{~h}$, concentrated under reduced pressure, the basic water phase was washed with ethyl acetate $(10 \mathrm{~mL})$ and then acidified with $1 \mathrm{M} \mathrm{HCl}$ to $\mathrm{pH} 1$. The product was extracted with ethyl acetate $(3 \times 15 \mathrm{~mL})$, the combined organic phases washed with water $(3 \times 10 \mathrm{~mL})$ and brine $(10$ $\mathrm{mL}$ ), dried over $\mathrm{Na}_{2} \mathrm{SO}_{4}$, filtered and the solvent evaporated under reduced pressure. To the residue ether (15 mL) was added, the obtained suspension was sonicated, filtered, washed with ether (5 $\mathrm{mL}$ ) and dried to give $\mathbf{2 5 a}$ (42 $\mathrm{mg}$ ) as a pale brown solid.

4-(4,5-Dibromo-1H-pyrrole-2-carboxamido)benzoic acid (25a). Synthesized according to General procedure K. Pale brown solid; yield 62\% (42mg); mp: >300 ${ }^{\circ} \mathrm{C} ;{ }^{1} \mathrm{H}$ NMR (400 MHz, [D $\mathrm{D}_{6}$ ]DMSO): $\delta=7.29$ (d, $1 \mathrm{H},{ }^{4} J=2.8 \mathrm{~Hz}, \mathrm{Pyrr}-\mathrm{CH}$ ), 7.84 (d, 2H, ${ }^{3} J=8.8 \mathrm{~Hz}, \mathrm{Ar}-\mathrm{H}-3,5$ ), 7.93 (d, $\left.2 \mathrm{H},{ }^{3} \mathrm{~J}=8.8 \mathrm{~Hz}, \mathrm{Ar}-\mathrm{H}-2,6\right), 10.11$ (s, $\left.1 \mathrm{H}, \mathrm{CONH}\right), 12.71$ (br s, $\left.1 \mathrm{H}, \mathrm{COOH}\right), 13.00$ (d, $1 \mathrm{H},{ }^{4} \mathrm{~J}=2.4$ Hz, Pyrr-NH); ${ }^{13} \mathrm{C}$ NMR (100 MHz, [D $\left.\left.\mathrm{D}_{6}\right] \mathrm{DMSO}\right): \delta=98.28,106.57,114.35,119.02,125.19$, 127.55, 130.30, 142.97, 157.47, 166.91; IR (ATR): $v=3206,3121,3071,2965,2845,2656,2551$, 1669, 1592, 1408, 1316, 1226, 1175, 1119, 975, 850, 768, $691 \mathrm{~cm}^{-1}$; MS (ESI) m/z = 384.9 ([M$\mathrm{H}^{-}$); HRMS for $\mathrm{C}_{12} \mathrm{H}_{7} \mathrm{Br}_{2} \mathrm{~N}_{2} \mathrm{O}_{3}$ : calculated 384.8823, found 384.8827; HPLC: Agilent Eclipse Plus C18 column ( $4.6 \mathrm{~mm} \times 150 \mathrm{~mm}$ ); mobile phase: 30-90\% acetonitrile in TFA (0.1\%) in $16 \mathrm{~min}$, $90 \%$ acetonitrile to $20 \mathrm{~min}$; flow rate $1 \mathrm{~mL} / \mathrm{min}$; injection volume $10 \mu \mathrm{L}$; retention time: 8.485 (96.1\% at $280 \mathrm{~nm})$. 
Methyl 2-hydroxy-4-(4-nitrobenzamido)benzoate (26). The solution of 4-nitrobenzoyl chloride (1) (0.550 g, $2.96 \mathrm{mmol}$ ) and methyl 4-amino-3-hydroxybenzoate (23b) (495 mg, 2.96 $\mathrm{mmol})$ in anhydrous dichloromethane $(20 \mathrm{~mL})$ and pyridine $(10 \mathrm{~mL})$ was stirred at $\mathrm{rt}$ for $15 \mathrm{~h}$. The solvent was removed under reduced pressure, the residue was dissolved in ethyl acetate (40 mL) and washed with water $(2 \times 15 \mathrm{~mL})$, aqueous $\mathrm{NaHCO}_{3}$ solution $(3 \times 15 \mathrm{~mL})$ and brine $(2 \times 10 \mathrm{~mL})$. The organic phase was dried over $\mathrm{Na}_{2} \mathrm{SO}_{4}$, filtered and the solvent evaporated under reduced pressure. To the crude product ether $(15 \mathrm{~mL})$ was added, the obtained suspension sonicated, filtered off, washed with ether (2 × $5 \mathrm{~mL})$ and dried to obtain 26 (641 mg) as a white solid. Yield 68\% (641 mg), mp: 200-202 ${ }^{\circ} \mathrm{C}$; ${ }^{1} \mathrm{H}$ NMR (400 MHz, [D 6 DMSO): $\delta=3.89$ (s, 3H, CH 3 ), 7.36 (dd, $1 \mathrm{H},{ }^{3} J=$ $\left.8.8 \mathrm{~Hz},{ }^{4} \mathrm{~J}=2.0 \mathrm{~Hz}, \mathrm{Ar}-\mathrm{H}-5\right), 7.58$ (d, $\left.1 \mathrm{H} ;{ }^{4} \mathrm{~J}=2.0 \mathrm{~Hz}, \mathrm{Ar}-\mathrm{H}-3\right), 7.81$ (d, $\left.1 \mathrm{H},{ }^{3} \mathrm{~J}=8.8 \mathrm{~Hz}, \mathrm{Ar}-\mathrm{H}-6\right)$, 8.18 (d, 2H, ${ }^{3} \mathrm{~J}=9.2 \mathrm{~Hz}, \mathrm{Ar}-\mathrm{H}-2 ', 6$ '), 8.38 (d, 2H, $\left.{ }^{3} \mathrm{~J}=9.2 \mathrm{~Hz}, \mathrm{Ar}-\mathrm{H}-3 ', 5 '\right), 10.65$ (s, 1H, NH/OH), 10.80 (s, $1 \mathrm{H}, \mathrm{OH} / \mathrm{NH}) ;{ }^{13} \mathrm{C} \mathrm{NMR}\left(100 \mathrm{MHz},\left[\mathrm{D}_{6}\right] \mathrm{DMSO}\right): \delta=52.27\left(\mathrm{CH}_{3}\right), 107.36,108.30,111.43$, 123.56, 129.37, 130.72, 140.10, 145.10, 149.28, 160.93, 164.63, 168.88; IR (ATR): $v=3380,3112$, 2961, 1694, 1663, 1519, 1436, 1344, 1299, 1155, 1090, 954, 848, 710, 693, $631 \mathrm{~cm}^{-1}$; MS (ESI) $\mathrm{m} / \mathrm{z}=315.27\left([\mathrm{M}-\mathrm{H}]^{-}\right)$.

Methyl 4-(4-aminobenzamido)-2-hydroxybenzoate (27). Synthesized according to General procedure A. After evaporation of the solvent, ether $(20 \mathrm{~mL})$ was added to the residue, the obtained suspension sonicated, filtered, washed with ether $(2 \times 5 \mathrm{~mL})$ and dried to afford 27 (458 $\mathrm{mg})$ as white solid. Yield 83\% (458 mg); mp: $207-210{ }^{\circ} \mathrm{C}$; ${ }^{1} \mathrm{H}$ NMR (400 MHz, [D6]DMSO): $\delta=3.88$ (s, $3 \mathrm{H}, \mathrm{CH}_{3}$ ), 5.87 (s, 2H, NH ), 6.61 (d, 2H, $\left.{ }^{3} \mathrm{~J}=8.8 \mathrm{~Hz}, \mathrm{Ar}-\mathrm{H}-3^{\prime}, 5^{\prime}\right), 7.34$ (dd, $1 \mathrm{H},{ }^{3} \mathrm{~J}=8.8 \mathrm{~Hz},{ }^{4} \mathrm{~J}=$ $2.0 \mathrm{~Hz}, \mathrm{Ar}-\mathrm{H}-5), 7.58$ (d, 1H, ${ }^{4} \mathrm{~J}=2.0 \mathrm{~Hz}, \mathrm{Ar}-\mathrm{H}-3$ ), 7.71-7.75 (m, 3H, Ar-H-2',6', Ar-H-6), 10.02 (s, 1H, NH), 10.63 (s, 1H, OH); ${ }^{13} \mathrm{C}$ NMR (100 MHz, [D 6 DMSO): $\delta=52.16\left(\mathrm{CH}_{3}\right), 106.57$, 106.80, 111.17, 112.48, 120.32, 129.66, 130.36, 146.51, 152.59, 161.15, 165.71, 169.18; MS (ESI) $\mathrm{m} / \mathrm{z}=285.26\left([\mathrm{M}-\mathrm{H}]^{-}\right)$; IR (ATR): $v$ = 3417, 3362, 3323, 32153101 2961, 2858, 1660, 1505, 1439, 1348, 1238, 1195, 1148, 1076, 956, 834, 722, $660 \mathrm{~cm}^{-1}$.

\section{Methyl 4-(4-(4,5-dibromo-1H-pyrrole-2-carboxamido)benzamido)-2-hydroxybenzoate} (28). To a suspension of 4,5-dibromopyrrole-2-carboxylic acid (338 mg, $1.26 \mathrm{mmol}$ ) in anhydrous dichloromethane (10 mL) oxalyl chloride (2 M solution in dichloromethane, $3.8 \mathrm{~mL}, 7.55 \mathrm{mmol}$ ) was added and the mixture was stirred at rt for $15 \mathrm{~h}$. The solvent was removed under reduced pressure, fresh anhydrous dichloromethane $(10 \mathrm{~mL})$, pyridine $(5 \mathrm{~mL})$ and compound 27 (290 mg, $1.01 \mathrm{mmol}$ ) were added and the reaction mixture was stirred at $\mathrm{rt}$ for $15 \mathrm{~h}$. The solvent was removed 
under reduced pressure, to the residue ethyl acetate $(30 \mathrm{~mL})$ and water $(15 \mathrm{~mL})$ were added. The undissolved solid was filtered off, phases were separated and the organic phase was washed with water $(2 \times 10 \mathrm{~mL})$, aqueous $\mathrm{NaHCO}_{3}$ solution $(3 \times 10 \mathrm{~mL})$ and brine $(2 \times 10 \mathrm{~mL})$, dried over $\mathrm{Na}_{2} \mathrm{SO}_{4}$, filtered and the solvent was removed under reduced pressure. The solid residue after extraction was combined with the filtered solid and acetonitrile (20 mL) was added, the obtained suspension was sonicated, heated, filtered off, washed with acetonitrile $(2 \times 5 \mathrm{~mL})$ and dried to give 28 (326 mg) as an off-white solid. Yield 60\% (326 mg); mp: >300 ${ }^{\circ} \mathrm{C} ;{ }^{1} \mathrm{H}$ NMR (400 MHz, [D6]DMSO): $\delta=3.89$ (s, 3H, CH 3 ), 7.30 (d, $1 \mathrm{H},{ }^{4} \mathrm{~J}=2.4 \mathrm{~Hz}$, Pyrr-CH), 7.37 (dd, $1 \mathrm{H},{ }^{3} \mathrm{~J}=8.8 \mathrm{~Hz}$, $\left.{ }^{4} J=2.0 \mathrm{~Hz}, \mathrm{Ar}-\mathrm{H}-5\right), 7.59$ (d, 1H, $\left.{ }^{4} \mathrm{~J}=2.0 \mathrm{~Hz}, \mathrm{Ar}-\mathrm{H}-3\right), 7.78$ (d, 1H, $\left.{ }^{3} \mathrm{~J}=8.8 \mathrm{~Hz}, \mathrm{Ar}-\mathrm{H}-6\right), 7.89$ (d,

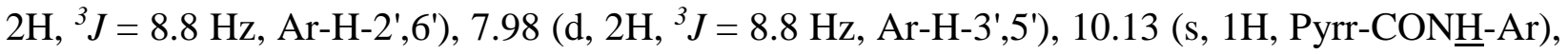
10.40 (s, 1H, Ar-CONㅌ-Ar), 10.65 (s, 1H, OH), 13.01 (d, 1H, $\left.{ }^{4} \mathrm{~J}=2 \mathrm{~Hz}, \mathrm{Pyrr}-\mathrm{NH}\right) ;{ }^{13} \mathrm{C}$ NMR (100 $\left.\mathrm{MHz},\left[\mathrm{D}_{6}\right] \mathrm{DMSO}\right): \delta=52.23\left(\mathrm{CH}_{3}\right), 98.29,106.56,106.97,107.54,111.31,114.30,118.98$, 127.58, 128.81, 130.56, 142.25, 145.85, 157.47, 161.06, 165.45, 169.05, two signals are overlapping; IR (ATR): $v=3444,3357,3194,2964,1658,1504,1406,1324,1275,1185,1092$, 972, 826, 779, $684 \mathrm{~cm}^{-1}$; MS (ESI) m/z = 533.9 ([M-H]'); HRMS for $\mathrm{C}_{20} \mathrm{H}_{15} \mathrm{Br}_{2} \mathrm{~N}_{3} \mathrm{O}_{5}$ : calculated 533.9300, found 533.9299; HPLC: Agilent Eclipse Plus C18 column (4.6 mm × $150 \mathrm{~mm}$ ); mobile phase: $60-90 \%$ of methanol in $0.1 \%$ TFA in $16 \mathrm{~min}, 90 \%$ methanol to $20 \mathrm{~min}$; flow rate $1 \mathrm{~mL} / \mathrm{min}$; injection volume $10 \mu \mathrm{L}$; retention time: 11.480 (95.9\% at $280 \mathrm{~nm})$.

\section{4-(4-(4,5-Dibromo-1H-pyrrole-2-carboxamido)benzamido)-2-hydroxybenzoic acid (29).}

Synthesized according to General procedure K without washing the residue with ethyl acetate before acidifying it. To the crude product methanol $(20 \mathrm{~mL})$ was added, the obtained suspension was sonicated, filtered off, washed with methanol $(2 \times 10 \mathrm{~mL})$ and ether $(2 \times 10 \mathrm{~mL})$ and dried to give 29 (50 mg) as a pale yellow solid. Yield 64\% (50 mg); mp: >300 ${ }^{\circ} \mathrm{C}$; ${ }^{1} \mathrm{H} \mathrm{NMR} \mathrm{(400} \mathrm{MHz,}$ [D6]DMSO): $\delta=7.30$ (d, $1 \mathrm{H},{ }^{4} \mathrm{~J}=2.8 \mathrm{~Hz}$, Pyrr-CH), 7.35 (dd, $1 \mathrm{H},{ }^{3} \mathrm{~J}=8.8 \mathrm{~Hz},{ }^{4} \mathrm{~J}=2.0 \mathrm{~Hz}, \mathrm{Ar}-\mathrm{H}-$ 5), 7.55 (d, 1H, $\left.{ }^{4} \mathrm{~J}=2.4 \mathrm{~Hz}, \mathrm{Ar}-\mathrm{H}-3\right), 7.76$ (d, 1H, $\left.{ }^{3} \mathrm{~J}=8.4 \mathrm{~Hz}, \mathrm{Ar}-\mathrm{H}-6\right), 7.88$ (d, 2H, ${ }^{3} \mathrm{~J}=9.2 \mathrm{~Hz}$,

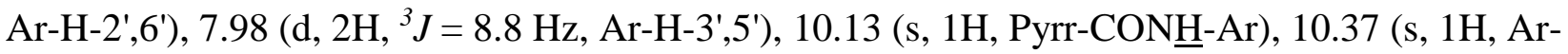

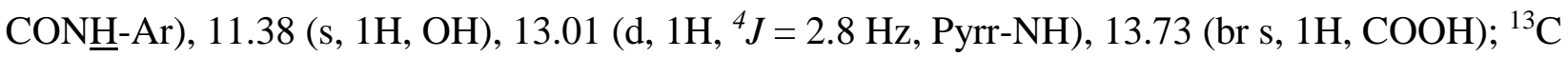
NMR (100 MHz, [D6]DMSO): $\delta=98.30,106.55,106.77,107.77,111.06,114.29,118.98,127.58$, 128.79, 128.87, 130.80, 142.21, 145.74, 157.46, 161.94, 165.43, 171.62; IR (ATR): $v=3406,3226$, 3110, 2547, 1644, 1498, 1334, 1229, 1111, 973, 892, 740, 671, $613 \mathrm{~cm}^{-1}$; MS (ESI) m/z = 519.9 ([M-H] $]^{-}$); HRMS for $\mathrm{C}_{19} \mathrm{H}_{13} \mathrm{Br}_{2} \mathrm{~N}_{3} \mathrm{O}_{5}$ : calculated 519.9144, found 519.9133; HPLC: Agilent 
Eclipse Plus C18 column (4.6 mm × $150 \mathrm{~mm}$ ); mobile phase: $30-90 \%$ acetonitrile in $0.1 \%$ TFA in $16 \mathrm{~min}, 90 \%$ acetonitrile to $20 \mathrm{~min}$; flow rate $1 \mathrm{~mL} / \mathrm{min}$; injection volume $10 \mu \mathrm{L}$; retention time: $10.212(96.5 \%$ at $280 \mathrm{~nm})$.

\section{Acknowledgments}

This work was supported by the Slovenian Research Agency (Grant No. P1-0208), EU FP7 Integrated Project MAREX (Project No. FP7-KBBE-2009-3-245137), EU H2020 ITN-ETN Project INTEGRATE (Project Reference: 642620), and Academy of Finland (Grant No. 277001 and 284477). We thank Dr. Dušan Žigon (Mass Spectrometry Center, Jožef Stefan Institute, Ljubljana, Slovenia) for recording mass spectra, Helena Macut, Nataša Šijanec and Francesca Magari for their help with chemical syntheses, and Heidi Mäkkylä and Cristina Carbonell Duacastella for their technical assistance in the antibacterial assays. The authors thank Prof. Roger Pain for proofreading the manuscript.

\section{Conflict of Interest}

The authors declare no conflict of interest.

Abbreviations: ATCC, American type culture collection; ATR, attenuated total reflectance; CDI, 1,1'-carbonyldiimidazole; CFU, colony-forming unit; CLSI, Clinical and Laboratory Standards Institute; DIAD, diisopropyl azodicarboxylate; DMAP, 4-dimethylaminopyridine; DTT, dithiothreitol; GyrA, DNA gyrase A; GyrB, DNA gyrase B; MH, Mueller Hinton; NMM, Nmethylmorpholine; ParC, topoisomerase IV subunit A; ParE, topoisomerase IV subunit B; RA, residual activity; TBTU, $N, N, N^{\prime}, N^{\prime}$-tetramethyl-O-(benzotriazol-1-yl)uronium tetrafluoroborate; topo IV, topoisomerase IV

Keywords: antibacterials; DNA gyrase; GyrB; inhibitors; pyrrolamide

\section{References}

[1] a) C. R. Strachan, J. Davies, Csh. Perspect. Med. 2017, 7; b) E. D. Brown, G. D. Wright, Nature 2016, 529, 336-343; c) R. Tommasi, D. G. Brown, G. K. Walkup, J. I. Manchester, A. A. Miller, Nat. Rev. Drug Discov. 2015, 14, 529-542; d) L. L. Silver, Clin. Microbiol. Rev. 2011, 24, 71-109.

[2] G. S. Bisacchi, J. I. Manchester, ACS Infect. Dis. 2015, 1, 4-41.

[3] D. M. Shlaes, D. Sahm, C. Opiela, B. Spellbergc, Antimicrob. Agents Ch. 2013, 57, 4605-4607. 
[4] a) C. Mayer, Y. L. Janin, Chem Rev 2014, 114, 2313-2342; b) T. Tomašič, L. P. Mašič, Curr. Top. Med. Chem. 2014, 14, 130-151; c) M. Oblak, M. Kotnik, T. Solmajer, Curr. Med. Chem. 2007, 14, 2033-2047.

[5] A. M. Emmerson, A. M. Jones, J. Antimicrob. Chemoth. 2003, 51, 13-20.

[6] a) D. C. Hooper, G. A. Jacoby, Csh. Perspect. Med. 2016, 6; b) K. Drlica, M. Malik, Curr. Top. Med. Chem. 2003, 3, 249-282.

[7] G. S. Basarab, J. I. Manchester, S. Bist, P. A. Boriack-Sjodin, B. Dangel, R. Illingworth, B. A. Sherer, S. Sriram, M. Uria-Nickelsen, A. E. Eakin, J. Med. Chem. 2013, 56, 8712-8735.

[8] L. W. Tari, X. M. Li, M. Trzoss, D. C. Bensen, Z. Y. Chen, T. Lam, J. H. Zhang, S. J. Lee, G. Hough, D. Phillipson, S. Akers-Rodriguez, M. L. Cunningham, B. P. Kwan, K. J. Nelson, A. Castellano, J. B. Locke, V. Brown-Driver, T. M. Murphy, V. S. Ong, C. M. Pillar, D. L. Shinabarger, J. Nix, F. C. Lightstone, S. E. Wong, T. B. Nguyen, K. J. Shaw, J. Finn, Plos One 2013, 8.

[9] a) L. W. Tari, M. Trzoss, D. C. Bensen, X. M. Li, Z. Y. Chen, T. Lam, J. H. Zhang, C. J. Creighton, M. L. Cunningham, B. Kwan, M. Stidham, K. J. Shaw, F. C. Lightstone, S. E. Wong, T. B. Nguyen, J. Nix, J. Finn, Bioorg. Med. Chem. Lett. 2013, 23, 1529-1536; b) M. Trzoss, D. C. Bensen, X. M. Li, Z. Y. Chen, T. Lam, J. H. Zhang, C. J. Creighton, M. L. Cunningham, B. Kwan, M. Stidham, K. Nelson, V. Brown-Driver, A. Castellano, K. J. Shaw, F. C. Lightstone, S. E. Wong, T. B. Nguyen, J. Finn, L. W. Tari, Bioorg. Med. Chem. Lett. 2013, 23, 1537-1543.

[10] A. L. Grillot, A. Le Tiran, D. Shannon, E. Krueger, Y. S. Liao, H. O'Dowd, Q. Tang, S. Ronkin, T. S. Wang, N. Waal, P. Li, D. Lauffer, E. Sizensky, J. Tanoury, E. Perola, T. H. Grossman, T. Doyle, B. Hanzelka, S. Jones, V. Dixit, N. Ewing, S. K. Liao, B. Boucher, M. Jacobs, Y. Bennani, P. S. Charifson, J. Med. Chem. 2014, 57, 8792-8816.

[11] a) B. A. Sherer, K. Hull, O. Green, G. Basarab, S. Hauck, P. Hill, J. T. Loch, G. Mullen, S. Bist, J. Bryant, A. Boriack-Sjodin, J. Read, N. DeGrace, M. Uria-Nickelsen, R. N. Illingworth, A. E. Eakin, Bioorg. Med. Chem. Lett. 2011, 21, 7416-7420; b) A. E. Eakin, O. Green, N. Hales, G. K. Walkup, S. Bist, A. Singh, G. Mullen, J. Bryant, K. Embrey, N. Gao, A. Breeze, D. Timms, B. Andrews, M. Uria-Nickelsen, J. Demeritt, J. T. Loch, K. Hull, A. Blodgett, R. N. Illingworth, B. Prince, P. A. Boriack-Sjodin, S. Hauck, L. J. MacPherson, H. H. Ni, B. Sherer, Antimicrob. Agents Ch. 2012, 56, 1240-1246; c) M. Uria-Nickelsen, A. Blodgett, H. Kamp, A. Eakin, B. Sherer, O. Green, Int. J. Antimicrob. Ag. 2013, 41, 28-35; d) G. S. Basarab, P. J. Hill, C. E. Garner, K. Hull, O. Green, B. A. Sherer, P. B. Dangel, J. I. Manchester, S. Bist, S. Hauck, F. Zhou, M. Uria-Nickelsen, R. Illingworth, R. Alm, M. Rooney, A. E. Eakin, J. Med. Chem. 2014, 57, 6060-6082.

[12] a) J. B. Cross, J. Zhang, Q. Y. Yang, M. F. Mesleh, J. A. C. Romero, B. Wang, D. Bevan, K. M. Poutsiaka, F. Epie, T. Moy, A. Daniel, J. Shotwell, B. Chamberlain, N. Carter, O. Andersen, J. Barker, M. D. Ryan, C. A. Metcalf, J. Silverman, K. Nguyen, B. Lippa, R. E. Dolle, ACS Med. Chem. Lett. 2016, 7, 374-378; b) M. F. Mesleh, J. B. Cross, J. Zhang, J. Kahmann, O. A. Andersen, J. Barker, R. K. Cheng, B. Felicetti, M. Woodc, A. T. Hadfield, C. Scheich, T. I. Moya, Q. Y. Yang, J. Shotwell, K. Nguyen, B. Lippa, R. Dolle, M. D. Ryan, Bioorg. Med. Chem. Lett. 2016, 26, 1314-1318.

[13] L. L. Silver, Bioorg. Med. Chem. 2016, 24, 6379-6389.

[14] N. Zidar, H. Macut, T. Tomašič, M. Brvar, S. Montalvão, P. Tammela, T. Solmajer, L. P. Mašič, J. Ilaš, D. Kikelj, J. Med. Chem. 2015, 58, 6179-6194.

[15] a) T. Tomašič, S. Katsamakas, Ž. Hodnik, J. Ilaš, M. Brvar, T. Solmajer, S. Montalvão, P. Tammela, M. Banjanac, G. Ergovic, M. Anderluh, L. P. Mašič, D. Kikelj, J. Med. Chem. 2015, 58, 5501-5521; b) N. Zidar, T. Tomašič, H. Macut, A. Sirc, M. Brvar, S. Montalvão, P. Tammela, J. Ilaš, D. Kikelj, Eur. J. Med. Chem. 2016, 117, 197-211.

[16] a) P. S. Charifson, A. L. Grillot, T. H. Grossman, J. D. Parsons, M. Badia, S. Bellon, D. D. Deininger, J. E. Drumm, C. H. Gross, A. LeTiran, Y. S. Liao, N. Mani, D. P. Nicolau, E. Perola, S. Ronkin, D. Shannon, L. L. Swenson, Q. Tang, P. R. Tessier, S. K. Tian, M. Trudeau, T. S. Wang, Y. Y. Wei, H. Zhang, D. Stamos, J. Med. Chem. 2008, 51, 5243-5263; b) S. Bellon, J. D. Parsons, Y. Y. Wei, K. Hayakawa, L. L. Swenson, P. S. Charifson, J. A. Lippke, R. Aldape, C. H. Gross, Antimicrob. Agents Ch. 2004, 48, 1856-1864.

[17] a) S. B. Singh, Bioorg. Med. Chem. 2016, 24, 6291-6297; b) J. W. Phillips, M. A. Goetz, S. K. Smith, D. L. Zink, J. Polishook, R. Onishi, S. Salowe, J. Wiltsie, J. Allocco, J. Sigmund, K. Dorso, S. Lee, S. Skwish, M. de la Cruz, J. Martin, F. Vicente, O. Genilloud, J. Lu, R. E. Painter, K. Young, K. Overbye, R. G. K. Donald, S. B. Singh, Chem. Biol. 2011, 18, 955-965.

[18] M. Brvar, A. Perdih, M. Renko, G. Anderluh, D. Turk, T. Solmajer, J. Med. Chem. 2012, 55, 6413-6426.

[19] a) T. E. Renau, R. Leger, E. M. Flamme, J. Sangalang, M. W. She, R. Yen, C. L. Gannon, D. Griffith, S. Chamberland, O. Lomovskaya, S. J. Hecker, V. J. Lee, T. Ohta, K. Nakayama, J. Med. Chem. 1999, 42, 49284931; b) O. Lomovskaya, M. S. Warren, A. Lee, J. Galazzo, R. Fronko, M. Lee, J. Blais, D. Cho, S. 
Chamberland, T. Renau, R. Leger, S. Hecker, W. Watkins, K. Hoshino, H. Ishida, V. J. Lee, Antimicrob. Agents Ch. 2001, 45, 105-116.

[20] S. Alt, L. A. Mitchenall, A. Maxwell, L. Heide, J. Antimicrob. Chemoth. 2011, 66, 2061-2069.

[21] T. Baba, T. Ara, M. Hasegawa, Y. Takai, Y. Okumura, M. Baba, K. A. Datsenko, M. Tomita, B. L. Wanner, H. Mori, Mol. Syst. Biol. 2006, 2.

[22] CLSI. Methods for Dilution Antimicrobial Susceptibility Tests for Bacteria That Grow Aerobically; Approved Standard-Ninth Edition. CLSI document M07-A9. Wayne, PA: Clinical and Laboratory Standards Institute; 2012

[23] GAMESS interface, Chem3D 16.0, ChemOffice Professional 16.0 Suite, CambridgeSoft

[24] T. A. Halgren, J. Comput. Chem. 1996, 17, 490-519.

[25] G. Jones, P. Willett, R. C. Glen, A. R. Leach, R. Taylor, J. Mol. Biol. 1997, 267, 727-748.

[26] GOLD Suite v5.4 is available from The Cambridge Crystallographic Data Centre, 12 Union Road, Cambridge, CB2 1EZ, UK, www.ccdc.cam.ac.uk.

[27] PyMOL, Delano Scientific LLC, San Francisco, CA, http://pymol.sourceforge.net.

[28] K. Miyatake, S. Kaga, Yakugaku Zasshi 1952, 72, 1160-1161.

[29] D. P. Walker, D. G. Wishka, D. W. Piotrowski, S. Jia, S. C. Reitz, K. M. Yates, J. K. Myers, T. N. Vetman, B. J. Margolis, E. J. Jacobsen, B. A. Acker, V. E. Groppi, M. L. Wolfe, B. A. Thornburgh, P. M. Tinholt, L. A. Cortes-Burgos, R. R. Walters, M. R. Hester, E. P. Seest, L. A. Dolak, F. Han, B. A. Olson, L. Fitzgerald, B. A. Staton, T. J. Raub, M. Hajos, W. E. Hoffmann, K. S. Li, N. R. Higdon, T. M. Wall, R. S. Hurst, E. H. Wong, B. N. Rogers, Bioorg. Med. Chem. 2006, 14, 8219-8248.

[30] M. Ishikawa, M. Tsushima, D. Kubota, Y. Yanagisawa, Y. Hiraiwa, Y. Kojima, K. Ajito, N. Anzai, Org. Process Res. Dev. 2008, 12, 596-602.

[31] I. A. Ismail, D. E. Sharp, M. R. Chedekel, J. Org. Chem. 1980, 45, 2243-2246. 


\section{Table of Contents}

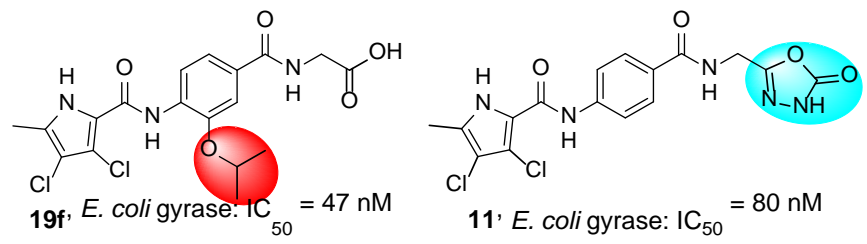

New N-phenylpyrrolamides were prepared as DNA gyrase and topoisomerase IV inhibitors and their structure-activity relationships were studied. Most potent compounds displayed $I C_{50}$ values lower than $100 \mathrm{nM}$ against $E$. coli gyrase. Minimum inhibitory concentration of $12.5 \mu \mathrm{M}$ was determined for $\mathbf{1 1}$ against Gram-positive $E$. faecalis. MICs against efflux pump deficient and against the $E$. coli strains in the presence of efflux pump inhibitor were studied. 